\title{
United Republic of Tanzania: Financial System Stability Assessment Update
}

This update to the Financial System Stability Assessment on the United Republic of Tanzania was prepared by a staff team of the International Monetary Fund as background documentation for the periodic consultation with the member country. It is based on the information available at the time it was completed on May 5, 2010. The views expressed in this document are those of the staff team and do not necessarily reflect the views of the government of the United Republic of Tanzania or the Executive Board of the IMF.

The policy of publication of staff reports and other documents by the IMF allows for the deletion of market-sensitive information.

\author{
Copies of this report are available to the public from \\ International Monetary Fund • Publication Services \\ $70019^{\text {th }}$ Street, N.W. • Washington, D.C. 20431 \\ Telephone: (202) 623-7430 • Telefax: (202) 623-7201 \\ E-mail: publications@imf.org Internet: http://www.imf.org
}

\section{International Monetary Fund Washington, D.C.}




\title{
INTERNATIONAL MONETARY FUND
}

\section{UNITED REPUBLIC OF TANZANIA}

\section{Financial System Stability Assessment Update}

\author{
Prepared by the Monetary and Capital Markets and African Departments \\ Approved by José Viñals and Antoinette Sayeh
}

May 5, 2010

\begin{abstract}
A joint World Bank-IMF team visited Tanzania September 9-23, 2009 to conduct a Financial Sector Assessment Program (FSAP) Update. The mission comprised S. Erik Oppers (co-Mission Chief, IMF); Michael Fuchs (co-Mission Chief, World Bank); Alan Roe, Antony Randle, David Porteous, Ed Al-Hussainy, Erik Feyen, Hemant Baijal, Michel Noel, Ravi Ruparel, Regina Martinez, Richard Hands, (all World Bank); Annamaria Kokenyne, Bozena Radzewicz-Bak, David Dunn, Keith Bell, and Mindaugas Leika (all IMF). The team received inputs from Adolfo Rouillon and Jose Garrido on the Creditor Rights and Corporate Insolvency ROSC, Richard Pratt on the IOSCO assessment, and Roman Didenko (FIRST Trust Fund). David Robinson, the Fund's Senior Resident Representative in Tanzania, participated in some of the meetings. The mission's findings were discussed with the authorities in March 2010 during the mission to conduct the Seventh Review of the PSI, the Second Review of the ESF and to negotiate a new three-year PSI. The FSAP mission's main findings are:
\end{abstract}

- $\quad$ The financial sector in Tanzania has undergone substantial structural change since the 2003 FSAP. Financial sector assets have expanded rapidly, led by growth in private credit. Yet the banking system remains small and relatively inefficient, and access to finance remains very low.

- $\quad$ Although systemic risk appears contained, vulnerabilities in the financial sector have heightened. Rapid credit growth has increased credit risk, especially from large single exposures, and a number of banks do not fully comply with provisioning requirements. There are remaining weaknesses in supervision (despite improvements since the 2003 FSAP), including weak enforcement, and gaps in prudential data collection and analysis that hamper a comprehensive assessment of risks in the financial sector. The authorities are urged to address these weaknesses.

- Key crisis management tools and components of a financial safety net are in place, but a comprehensive crisis management framework is lacking. Insufficient focus on systemic risk, the lack of an instrument for injecting emergency liquidity, and an underfunded Deposit Insurance Fund could significantly compound a financial shock. The authorities have begun to address these issues, in part with the help of Fund technical assistance.

The main author of this report is S. Erik Oppers, with substantial contributions from the FSAP and AFR teams. FSAP Assessments are designed to assess the stability of the financial system as a whole and not that of individual institutions. They have been developed to help countries identify and remedy weaknesses in their financial sector structure, thereby enhancing their resilience to macroeconomic shocks and cross-border contagion. FSAP assessments do not cover risks that are specific to individual institutions such as asset quality, operational or legal risks, or fraud. 


\section{Contents}

Page

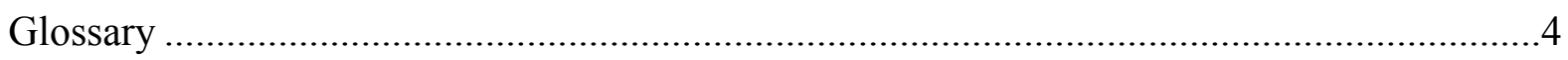

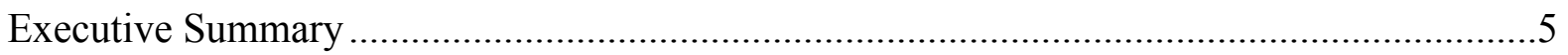

I. Macroeconomic Environment and Financial Structure …................................. 8

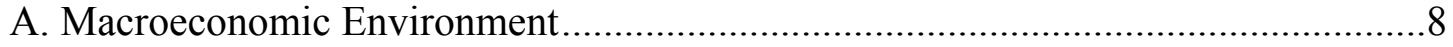

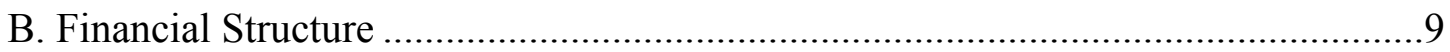

C. Financial Depth and Access ........................................................................ 10

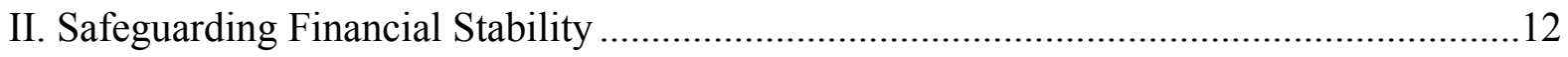

A. Risks and Vulnerabilities in the Banking System.......................................... 12

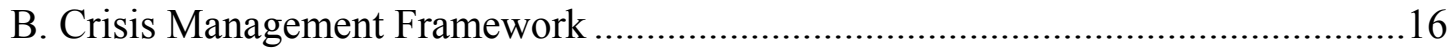

C. Banking Sector Regulation and Supervision.................................................. 17

D. Systemic Liquidity Management ..................................................................19

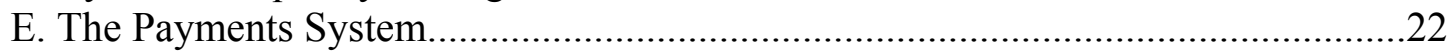

III. Longer-Term Finance ........................................................................................2

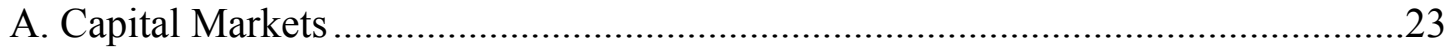

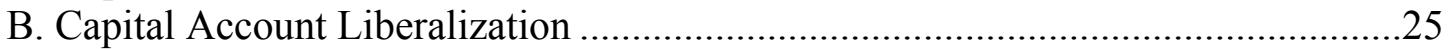

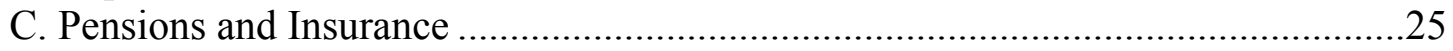

Tables

1. Selected Economic and Financial Indicators, 2006/07-2011/12 ...................................27

2. Financial System Structure, 2006-09 ..........................................................................28

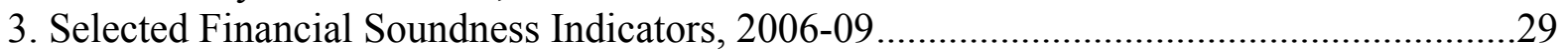

4. Compliance with Prudential Limits, end-December 2009 ...............................................30

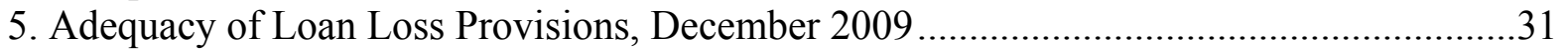

6. Stress Test Results — Default of Three Largest Borrowers.............................................32

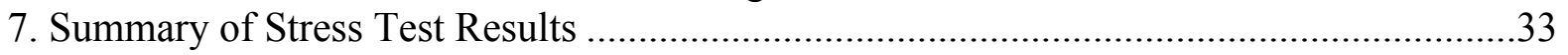

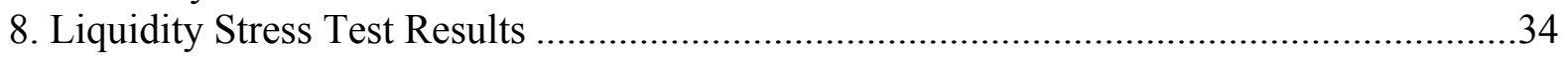

Figures

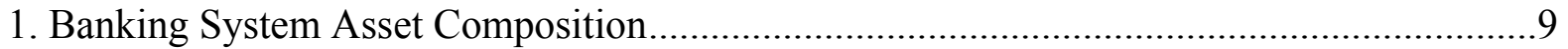

2. Net Interest Margin ............................................................................................... 10

3. Credit to the Private Sector and Domestic Deposits as a Share of GDP, 2008 .................11

4. Access to Financial Services Across Sub-Saharan Africa ...............................................11

5. Selected Financial Sector and Market Developments 2002-09 .....................................14

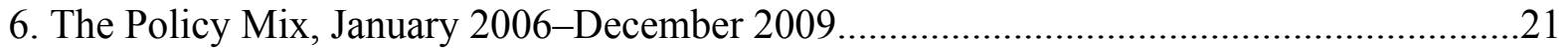

7. Money Market Transactions, January 2006-December 2009 .........................................21

8. Yield Curve for Government Bonds and Volume of 10-Year Bonds.................................23 
Boxes

1. Summary of Main Recommendations

2. Monetary Policy Tools of the Bank of Tanzania.

Appendices

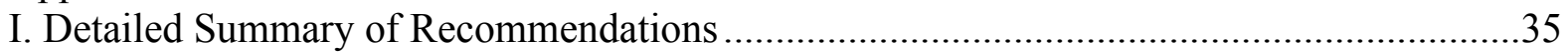

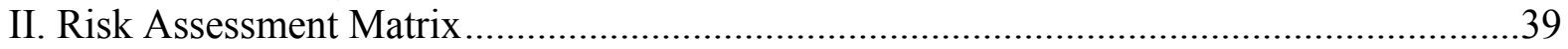

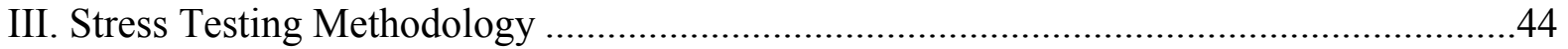

IV. Basel Core Principles Assessment_-Main Findings ........................................................49

Appendix Tables

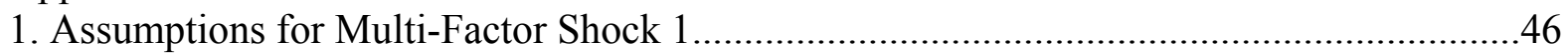

2. Recommended Action Plan..........................................................................................5

3. Summary Compliance of the Basel Core Principles........................................................58 


\section{GLOSSARY}

$\begin{array}{ll}\text { AML } & \text { Anti Money Laundering } \\ \text { ATM } & \text { Automated Teller Machine } \\ \text { BCP } & \text { Basel Core Principles for Effective Banking Supervision } \\ \text { BOT } & \text { Bank of Tanzania } \\ \text { BSD } & \text { Bank Supervision Department } \\ \text { CMSA } & \text { Capital Markets and Securities Authority } \\ \text { CAR } & \text { Capital Adequacy Ratio } \\ \text { CSD } & \text { Central Securities Depository } \\ \text { DSE } & \text { Dar es Salaam Stock Exchange } \\ \text { DBS } & \text { Directorate of Banking Supervision } \\ \text { DIF } & \text { Deposit Insurance Fund } \\ \text { DIB } & \text { Deposit Insurance Board } \\ \text { DSE } & \text { Dar es Salaam Stock Exchange } \\ \text { EASRA } & \text { East African Member States Securities Regulatory Authority } \\ \text { EFT } & \text { Electronic Funds Transfer } \\ \text { FDI } & \text { Foreign Direct Investment } \\ \text { FX } & \text { Foreign Exchange } \\ \text { GDP } & \text { Gross Domestic Product } \\ \text { IFRS } & \text { International Financial Reporting Standards } \\ \text { IOSCO } & \text { International Organization of Securities Commissions' } \\ & \text { Objectives and Principles of Securities Regulation } \\ \text { MFI } & \text { Microfinance Institution } \\ \text { MOFEA } & \text { Ministry of Finance and Economic Affairs } \\ \text { MOU } & \text { Memorandum of Understanding } \\ \text { OTC } & \text { Over-the-Counter } \\ \text { NBAA } & \text { National Board of Accountants and Auditors } \\ \text { NIC } & \text { National Insurance Corporation } \\ \text { NPLs } & \text { Nonperforming Loans } \\ \text { NPS } & \text { National Payment Systems } \\ \text { POD } & \text { Probabilities of Default } \\ \text { POS } & \text { Electronic Funds Transfer Point of Sale } \\ \text { RBS } & \text { Risk-Based Supervision } \\ \text { ROAA } & \text { Return on Average Assets } \\ \text { ROSCs } & \text { Reports on the Observance of Standards and Codes } \\ \text { RWA } & \text { Risk-weighted assets } \\ \text { SMR } & \text { Statutory Minimum Reserve requirements } \\ \text { SSRA } & \text { Social Security Regulatory Authority } \\ \text { T-bills } & \text { Treasury bills } \\ \text { TISS } & \text { Tanzania Interbank Settlement System } \\ & \end{array}$




\section{EXECUTIVE SUMMARY}

1. The financial sector in Tanzania has undergone substantial structural change since the 2003 FSAP. Financial sector assets have expanded rapidly, led by growth in private credit. This has enhanced financial intermediation, thereby increasingly supporting economic growth. The implementation of the Second Generation Financial Sector Reforms, drawing in part on recommendations from the 2003 FSAP, has underpinned these developments.

2. Yet the banking system remains small and relatively inefficient, and access to finance remains very low. Only one in six Tanzanians has access to financial services from formal institutions, which compares poorly to the country's peers. While efficiency is low, profitability remains strong as a result of wide interest margins. These persist as smaller banks have been unable to compete effectively with the larger banks, which are able, through their more extensive branch networks, to raise funds at very low cost.

\section{While systemic risk appears contained, vulnerabilities in the financial sector} have heightened. Rapid credit growth has been raising the ratio of private sector credit to gross domestic product (GDP) and associated credit risk. In the context of the global recession, the main vulnerability lies in exposures to distressed sectors (mainly cash crops, tourism, and transportation). Concentration in the loan portfolio is also of concern, as stress tests show that failure of their respective largest debtors would lead a number of banks to require additional capital. ${ }^{1}$

\section{Weaknesses remain in supervision, including in enforcement and prudential} data collection and analysis. The framework for banking supervision has been improved since the 2003 FSAP (including by putting it on a risk-based footing), but the mission found continuing compliance gaps with the Basel Core Principles (BCPs) for Effective Banking Supervision. Supervisory processes continue to not be fully risk-based, on-site inspection findings often lack adequate documentation and enforcement is weak, resulting in mixed compliance with prudential requirements. Underprovisioning appears widespread, although the mission's tentative analysis (hampered by incomplete data) shows that banks would need only limited additional capital to comply fully with the provisioning regulations. Moreover, gaps in prudential data collection and analysis prevent a comprehensive assessment of systemic and individual risks in the financial sector and the authorities are urged to address these gaps with urgency.

5. Important crisis management tools and components of a financial safety net are in place, yet important shortcomings exist and are being addressed by the authorities. The crisis management framework appears adequate for resolution of individual banks, but

\footnotetext{
${ }^{1}$ Total recapitalization costs after bankruptcy of the largest debtor of each of the system's 10 largest banks would total 0.2 percent of GDP.
} 
less so for a widespread crisis. Insufficient focus on systemic risk, the lack of an instrument for injecting emergency liquidity, and an underfunded Deposit Insurance Fund could compound a financial shock and should be addressed. With Fund technical assistance, the authorities are making enhancements to crisis preparedness that include detailed contingency plans, an explicit framework for systemic emergency liquidity assistance and recapitalization, institutional arrangements for cooperation among government agencies, and regular crisis simulation exercises.

\section{Systemic liquidity management has improved since the 2003 FSAP, but there is} scope for further strengthening. The operational framework has been clarified, with sales of foreign exchange and government securities as the main tools for removing structural injections of liquidity resulting from external budget support, but a clearer distinction is needed between sterilization and intervention objectives in exchange market operations. Efforts have been made to improve liquidity forecasting, and conditions in the money market have become less volatile, although this is partly due to excess liquidity in the system.

\section{Capital market development, still at a nascent stage in Tanzania, is important} for increasing access to long-term funding and providing suitable placements for institutional investors. Tanzania's security market stands to benefit considerably from closer integration in the East African Community (EAC), which will allow economies of scale and sharing of market infrastructure. Successful implementation of current plans to liberalize capital flows requires proper sequencing of reforms and implementation of supporting policies. Reform of the pension sector - and particularly bringing the Social Security Regulatory Authority into operation without delay-will be crucial, both to prevent accumulation of potential fiscal liabilities and to provide a stable source of longer-term financing. 


\section{Box 1. Summary of Main Recommendations ${ }^{2}$}

\section{Financial Structure}

- Consider raising minimum bank capital requirements to promote consolidation.

- Abolish loan-to-deposit ceiling (currently 80 percent).

- Pass regulations for Credit Bureau; create database for credit information and identification of debtors.

- Grant exclusive jurisdiction over enforcement of creditor claims to commercial courts.

- Design and implement comprehensive reform of civil procedure to reduce intentional delays by debtors.

\section{Safeguarding Financial Stability}

\section{Risks and Vulnerabilities in the Banking System}

- Improve timeliness and quality of prudential data; establish consistent data set for macroprudential analysis.

- Be more proactive in ensuring compliance with prudential limits, including on provisioning and large exposures.

\section{Crisis Management Framework}

- Establish a systemic crisis management plan and framework for emergency liquidity assistance; bolster reserves of the Deposit Insurance Fund.

\section{Banking Sector Regulation and Supervision}

- Address capacity and organizational challenges in banking supervision and reduce hierarchy in the communication protocol between the BOT and banks.

- Increase cooperation with "home" regulators of major international banks and their internal audit services.

- Seek hands-on technical assistance to ensure full implementation of all aspects of risk-based supervision.

Systemic Liquidity

- Distinguish clearly between sterilization and intervention objectives in foreign exchange (FX) interventions; limit REPOs to fine-tuning operations and Statutory Minimum Reserve requirements (SMRs) for long-term structural liquidity sterilization.

- Expedite movement of government deposits from commercial banks to the BOT.

\section{Promoting Long-Term Finance}

\section{Securities Markets}

- Design and implement an effective risk management system for securities settlement.

- Confer adequate supervisory powers on the Capital Markets and Securities Authority (CMSA); adopt and apply legislation requiring demutualization of the Dar es Salaam Stock Exchange (DSE) and splitting the DSE and the Central Securities Depository (CSD) into separate corporations.

\section{Capital Flows and Capital Account Liberalization}

- Revise capital account liberalization plan to ensure that lifting of controls is properly sequenced and supported by other policies.

\section{Pensions}

- Finalize establishment of Social Security Regulatory Authority and commence operations without delay.

- Replace fund-specific laws with single common pension law.

\footnotetext{
${ }^{2}$ For recommended timing, see Appendix I.
} 


\section{Macroeconomic EnVIRONMENT ANd Financial Structure}

\section{A. Macroeconomic Environment}

8. The global recession has had a significant impact on economic performance and the outlook in Tanzania (Table 1). Export sectors led a decline in real GDP growth to about 5.5 percent in 2009 , from some $7 \frac{1}{2}$ percent in 2008 , while key sources of capital — notably FDI and syndicated loans from abroad - have contracted, compounding the effects on the balance of payments of portfolio outflows. Better performance in some sectors (including construction, telecommunications, and food crops) and a fiscal stimulus of 5 percent of GDP is helping to moderate the slowdown with GDP growth expected to pick up in 2010, but there are still downside risks to the outlook.

9. Tanzanian banks were not directly affected by the global financial crisis, but second-round effects of the crisis have intensified the risks to the financial sector (see Risk Assessment Matrix in Appendix II). Going into the crisis, banks were well-capitalized and not exposed to the asset classes that led to large losses in major financial centers. However, exposure to distressed sectors (including cash crops, tourism, and transportation) has affected loan quality in a number of banks - including some larger institutions. Other financial institutions, such as the rapidly growing and inadequately supervised pension funds, could also be affected by a deterioration of asset quality, including in the real estate sector, which make up a growing part of asset portfolios.

10. Domestic liquidity tightened considerably at the onset of the global financial crisis but has since eased, owing to a significant loosening of monetary policy to help mitigate the economic downturn. In January 2009 the BOT increased the reserve requirement on government deposits held in commercial banks and no longer permitted the use of cash-in-vault to meet required reserves, leading to liquidity shortages for some banks and a spike in money market rates. Liquidity returned to ample levels in April 2009, when the BOT eased its monetary policy stance to encourage the flow of credit.

11. The policy response of the authorities included a rescue package designed to support sectors affected by the crisis. ${ }^{3}$ The mission noted the risks related to market distortion and moral hazard of compensating banks for loan losses; in response, financial support was offered to cotton and coffee traders directly, rather than to the banks. Funds were nevertheless channeled through the banks, however, to ensure that they were used for resolving nonperforming loans (NPLs) rather than for other purposes.

\footnotetext{
${ }^{3}$ For more details on the rescue package, see the Staff Report for $6^{\text {th }}$ Review of the PSI and $1^{\text {st }}$ Review of the ESF, EBS/09/180.
} 


\section{B. Financial Structure}

12. The banking system in Tanzania has grown significantly since 2003, but remains relatively small and dominated by a top tier of larger domestic legacy and foreign banks (Table 2). The top tier mainly caters to a small group of large corporates-which often represent up to 70 percent of banks' loan portfolios-leaving the retail market underserved. Government ownership is limited to four smaller fully-owned banks and minority stakes in the three largest domestic banks. Tanzanian banks have very limited operations abroad (one bank is active in Cyprus), and linkages with other financial institutions are largely absent.

\section{Overall efficiency in the banking system remains weak, but especially the larger} banks are profitable as a result of high interest margins. Since 2003, the banking system's overhead costs to total assets ratio has not significantly declined and remains high at 5.7 percent (although this is in line with the regional average). Large banks' networks allow them to mobilize ample, low-cost deposits at interest rates of between 1 percent and 2.5 percent, while a significant portion of assets is still invested in government securities with yields up to 20 percent (Figure 1), leading to high interest margins (Figure 2). As a result, the three largest banks achieved a return on assets in 2008 of 3.1 percent, exceeding the regional average of 2.5 percent.

Figure 1. Tanzania: Banking System Asset Composition, 2001-09

(In percent)

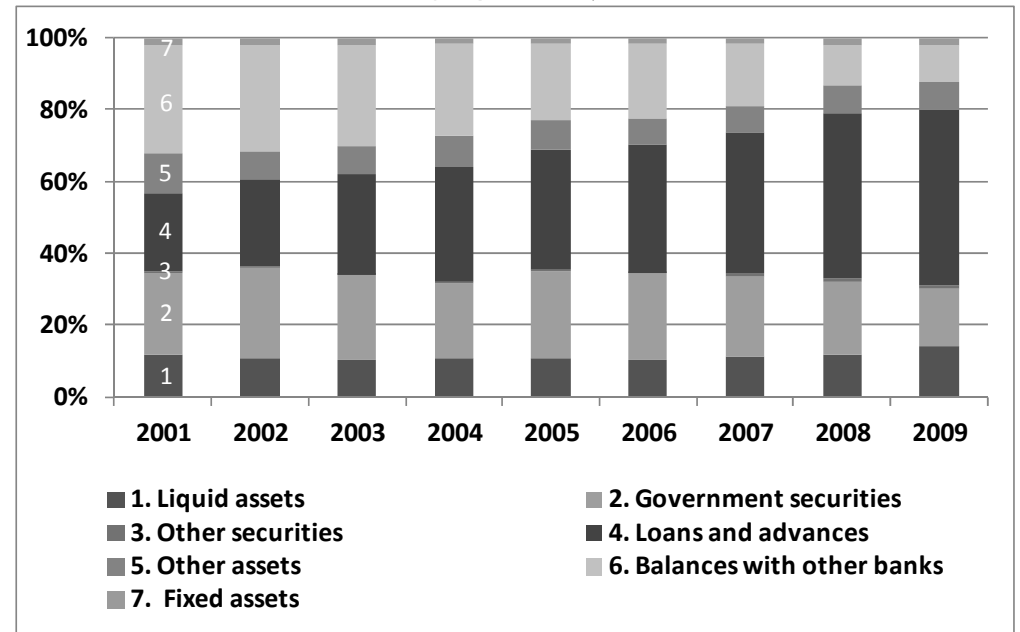

Source: BOT.

14. Smaller banks, lacking extended branch networks, have been unable to compete with the larger banks and concentration remains high. Since 2003, the asset share of the three largest banks (all previously government-owned) only declined slightly, from 66 percent to 64 percent. The BOT could promote consolidation of medium-sized banks to contest the top tier by judiciously raising minimum capital requirements. In addition, the current 80 percent loan to deposit ceiling puts the smaller banks at a disadvantage and the 
authorities could consider removing it. It is an unusual prudential requirement, the requirement is frequently waived, and 8 banks exceeded it as of end-2009.

Figure 2. Tanzania: Net Interest Margin, 2008

(In percent)

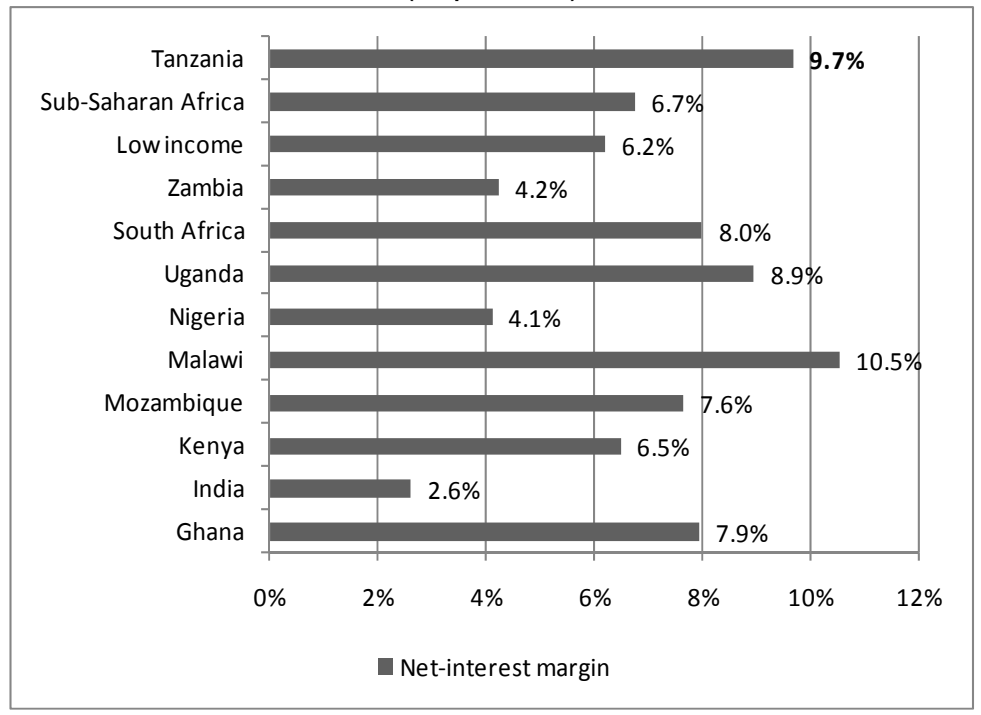

Source: Bankscope.

\section{Financial Depth and Access ${ }^{4}$}

\section{Despite rapid asset growth in recent years, private credit and deposit}

mobilization levels still lag behind countries in the region (Figure 3 ). The ratio of private credit to GDP rose from 5 to 16 percent of GDP during 2003-09, but remains below the regional average of 28 percent. Similarly, domestic deposits increased from 15 to 25 percent of GDP in the same period, compared to the regional average of 44 percent. Factors that have impeded a further increase in intermediation include a poor business environment, historically high interest rates on government securities, low competition, high profitability, lack of longer-term funding, and the loan-to-deposit ceiling.

\section{Only one in six Tanzanians have access to financial services from formal} institutions, which compares poorly to the country's peers (Figure 4). This share has increased since 2006, however, when formal access stood at only 11 percent. An additional 27 percent of the population is served by informal village associations, but over half of the population is financially excluded; this share has remained largely unchanged since 2006. Rural areas are particularly underserved: the rural parts of most regions reported an access rate of less than 10 percent.

\footnotetext{
${ }^{4}$ Issues of access to finance, as well as development, housing, and infrastructure finance are covered in more detail in the World Bank's Financial Sector Assessment.
} 
Figure 3. Tanzania: Private Credit and Domestic Deposits as a Share of GDP, 2008
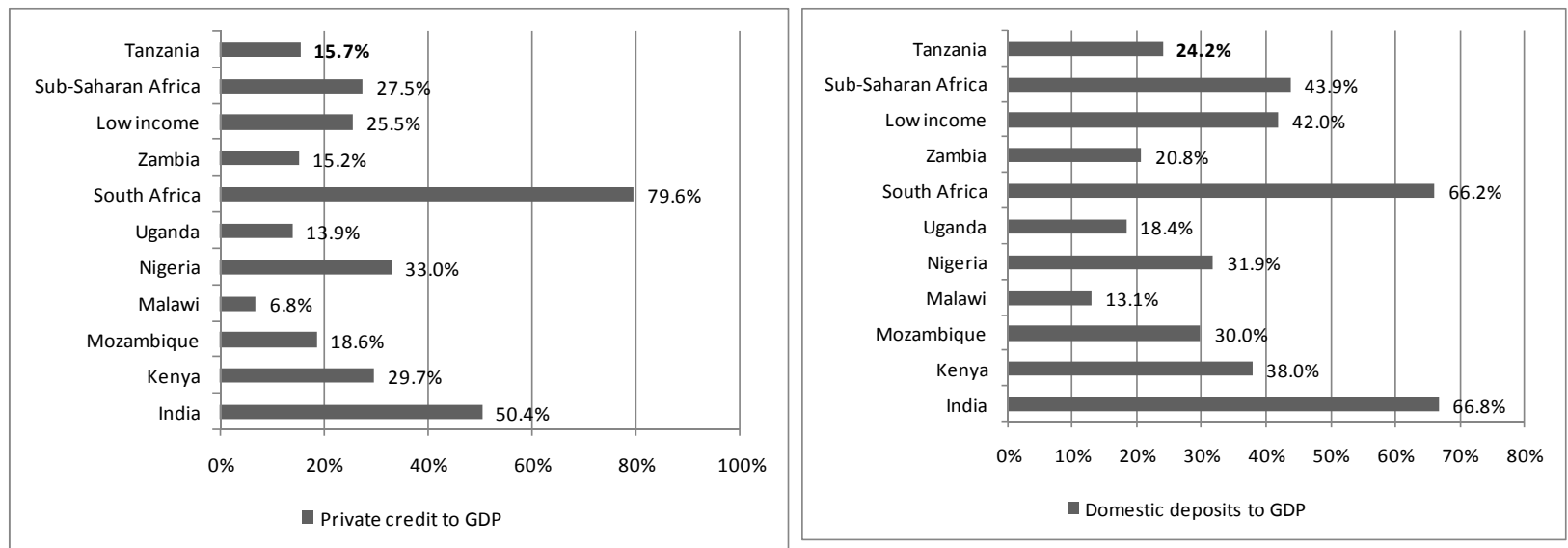

Source: BOT.

Figure 4. Tanzania: Access to Financial Services Across Sub-Saharan Africa (In percent)

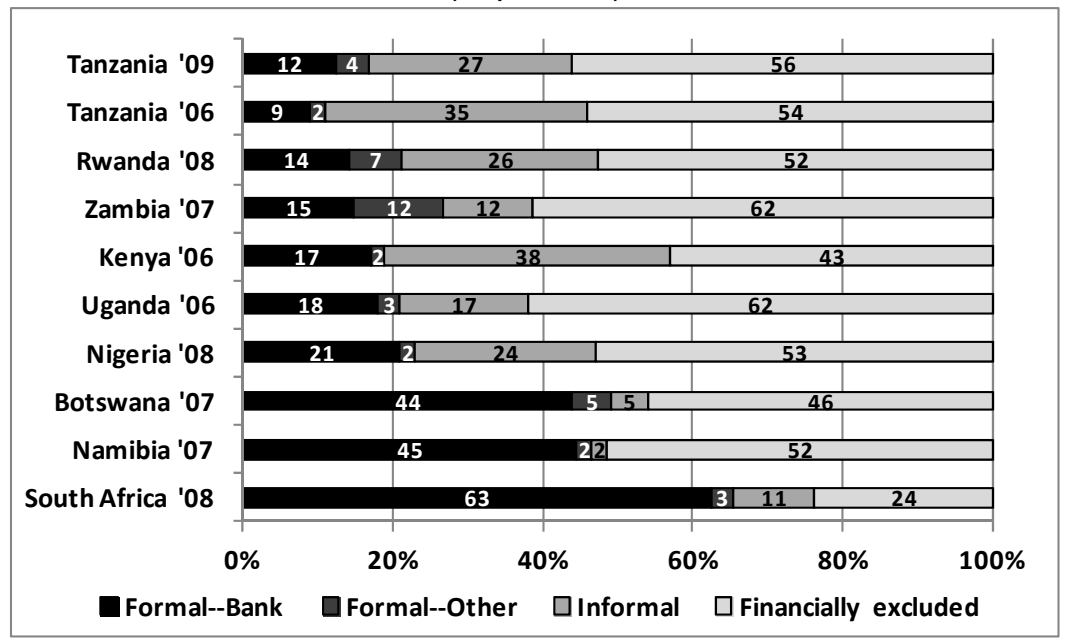

Source: FinScope.

17. The lack of a reliable credit information system and weak creditor rights restrict credit access and contribute to a high cost of credit. The procedures to create security interests are less than reliable and cumbersome, and the enforcement of claims is lengthy, unpredictable, and suffers from legal complications that can be used by debtors to delay proceedings. Credit information and creditor rights could be substantively enhanced with a series of legal and institutional reforms that include: (i) the creation of a Credit Bureau with mechanisms to uniquely identify debtors; (ii) granting exclusive jurisdiction over enforcement of creditor claims to commercial courts; and (iii) implementing a comprehensive reform of civil procedure to reduce use of delay tactics by debtors, including by limiting the number of available appeals. 


\section{Safeguarding Financial Stability}

\section{A. Risks and Vulnerabilities in the Banking System}

18. The 2003 FSAP concluded that banks were generally liquid, well-capitalized, and resilient to most shocks. The system had a capital ratio in excess of 20 percent, and relatively low lending activity limited the extent of credit risk, while exchange-rate risk was well-contained. The main vulnerability stemmed from interest-rate risk, with banks holding a significant share of assets in government bonds.

\section{The FSAP Update mission found that data deficiencies hampered its analysis of} risks in the financial sector and the authorities are urged to improve data quality and timeliness. Data provided to the mission on NPLs and provisions contained inconsistencies, including individual bank data that appeared not to correspond with available information about prudential compliance. The mission was unable to obtain detailed data on smaller banks, where weaknesses are concentrated. It is recommended that the authorities compile a consistent and timely data set for macroprudential analysis, including stress tests. The new system of electronic transmission of prudential data by banks could provide a sound basis for such a set, but data verification, retrieval and analysis needs to be improved. If necessary, the authorities are urged to seek further technical assistance in this area.

20. While available financial soundness indicators (FSIs) (Table 3) show a banking sector that is on average still adequately capitalized, weaknesses exist in some (mostly smaller) banks. The system-average Tier I and Tier II Capital Adequacy Ratios (CARs) rose by almost 4 percentage points between 2008 and 2009, to between 18 percent and 19 percent for both (compared to prudential minima of 10 percent (Tier I) and 12 percent (Tier II)). ${ }^{5}$ The average CAR masks weakness in some systemically less important banks, with three recently falling below the required minimum.

\section{Vulnerabilities are heightened in part by uneven compliance with prudential} requirements (Table 4), and the BOT should be more proactive in ensuring compliance. The three undercapitalized banks at end-June were required to file a recapitalization plan with the BOT with a time-bound path to regain compliance. Although such corrective action is appropriate, it is recommended that the BOT take a more proactive stance to ensure that incipient problems in banks are addressed before they cause a breach of prudential limits. This would be especially important in the case of deteriorating CARs.

\footnotetext{
${ }^{5}$ The increase reflected two factors: (i) a more cautious attitude towards lending in the face of the global financial crisis, which has led to a reallocation towards less risky assets; and (ii) a change in the prudential regulations which allowed banks from June 2008 to include in regulatory capital 100 percent of audited and 50 percent of unaudited current profits. As an indication of the potential effect of this change on the CAR, the aggregate value of positive bank profits in 2009 amounted to 33/4 percent of aggregate risk-weighted assets.
} 
22. Underprovisioning by banks in particular appears widespread. While a lack of data prevents a full analysis, a substantial minority of the banks appear not fully to comply with the prudential provisioning requirements (Table 5). A simulation to bring provisions up to a level believed to be closer to prudential compliance (lack of data on the impact of government guarantees and collateral prevent an exact calculation) shows that six banks would be undercapitalized if they were to provision adequately, although most of these are not of systemic importance and total recapitalization costs would be small (totaling T Sh. 5 billion - 0.017 percent of GDP — for the six banks combined). Supervisors should work with banks to improve the quality of provisioning data and ensure compliance with the prudential requirements.

23. Risk in banks is focused around credit risk after rapid credit growth in recent years. Between 2003 and 2008 strong growth in private sector credit (Figure 5) raised the share of loans in banks' portfolios from 32 percent to 54 percent, exposing the sector to increased credit risk. In addition, the high rates of credit growth could signal a trend towards less robust loan underwriting practices and raises concerns about the possibility of a future deterioration in loan portfolio quality.

\section{Reported NPL rates peaked in mid-2009, but they exhibited large variation} among banks, partly reflecting different exposures to distressed sectors. System-wide NPLs rose to 7.8 percent in June 2009 from 6.2 percent in December 2008, but subsequently declined to 6.7 percent, partly as a result of the government rescue package for distressed borrowers. NPL rates vary greatly across banks: for the systemically important banks at endJune 2009, they ranged from 1.8 percent to 14.2 percent, with two banks reporting rates in excess of 10 percent. Much of the variation reflects different sectoral distributions of loans, especially in the agricultural and transportation sectors.

\section{Stress tests indeed confirm that the main vulnerability for banks stems from} credit risk, particularly from large exposures. The stress tests found the following: ${ }^{6}$

\section{- Substantial concentration in the loan portfolio leaves banks exposed to the failure}

of large borrowers (Table 6). Failure of the single largest exposure renders five of the largest 10 banks undercapitalized (with one insolvent), with a drop in the system-wide CAR of more than one-third to below 12 percent. The undercapitalized banks would require additional capital of 0.2 percent of GDP to return to the regulatory minimum capital level. It was reported, however, that the exposure of banks was limited through government guarantees or cash collateral covering some of these loans. The mission could not verify the extent to which this mitigated the impact of potential loan failures on banks, as it was unable to obtain accurate data on guarantees and collateral.

\footnotetext{
${ }^{6}$ See Appendix III for a detailed description of the stress tests performed, including the methodology used and the calibration of the shocks.
} 
Figure 5. Tanzania. Selected Financial Sector and Market Developments 2002-09
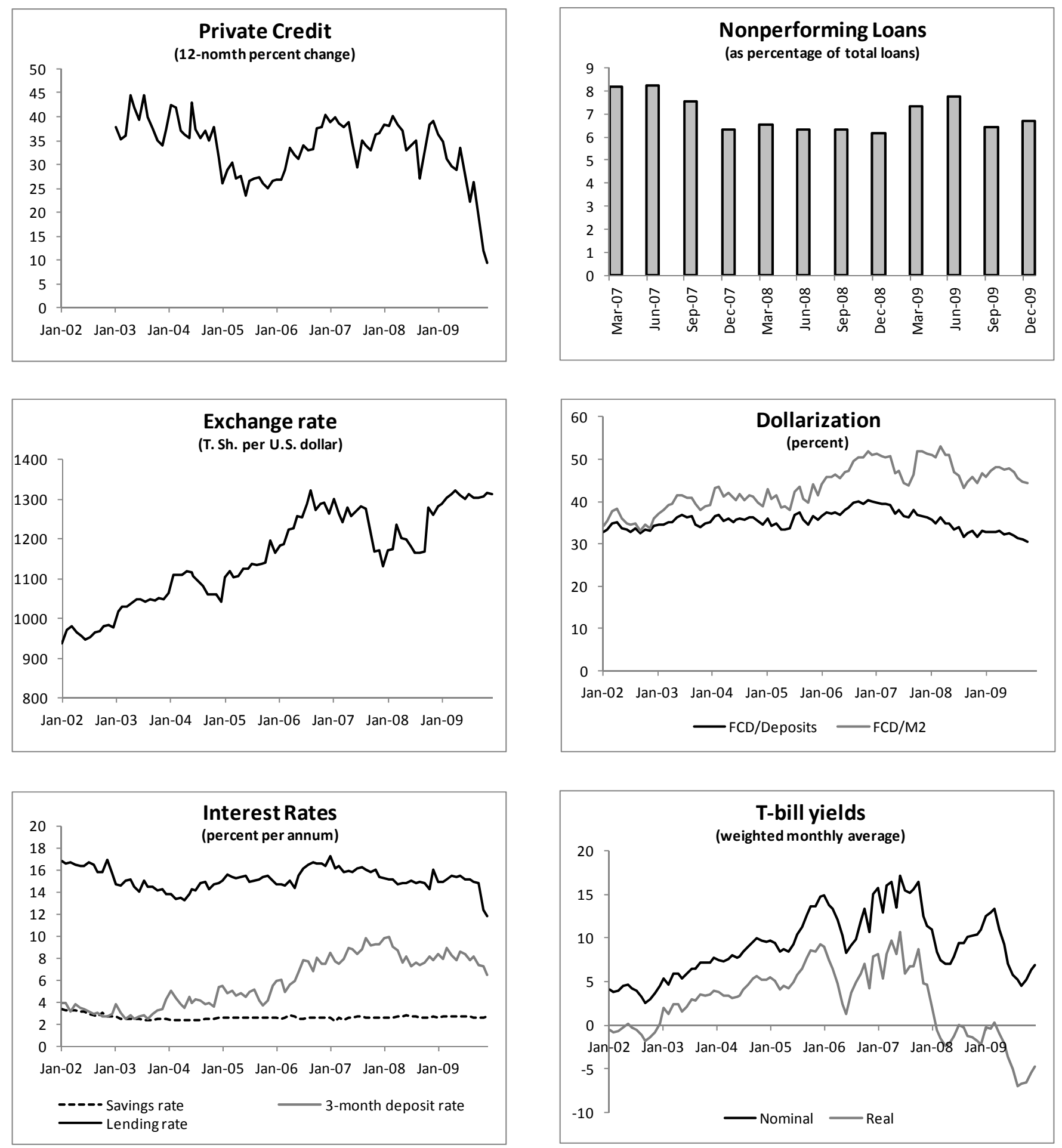

Source: BOT. 
- $\quad$ A sharp increase in short-term rates from today's very low levels would hurt a number of banks (Table 7). Were the yield curve to flatten out to where both short and long rates stand at 20 percent (reflecting increases of some 6 percentage points in long rates and 18 percentage points in short rates), a number of larger banks would show a sharp drop in net interest income, as mostly longer maturity assets would see yields rise less (and later) than mostly shorter maturity liabilities. ${ }^{7}$

- $\quad$ Foreign exchange risk is contained by relatively prudent management of open positions by banks. ${ }^{8}$ In stress tests, most banks would easily withstand appreciations and depreciations of 30 percent, partly as a result of prudent management of open positions. In addition, indirect (credit) risk is contained because borrowers in foreign currencies are concentrated in the tradable sectors, with exposures hedged through income in foreign currency.

- $\quad$ Liquidity stress tests confirm the ample liquidity in the system (Table 8). All banks are able to withstand a liquidity drain of 34 percent for demand deposits and 16 percent for time deposits in one day without recourse to interbank lending or emergency liquidity from the BOT. Most larger banks, except one medium-sized foreign subsidiary, could withstand a second day of such a substantial drain. Banks would cope well with a withdrawal of non-resident deposits, as these make up only a small proportion of total deposits.

- $\quad$ The comparison across all stress tests reveals that there are a number of consistently weaker (mostly smaller) banks, which also suffer in more comprehensive multifactor shocks. Banks with lower initial capital buffers suffer in most stress tests - enough to become undercapitalized. One larger foreign bank also suffers in two simulations of adverse macroeconomic scenarios, originating in (i) a drop in commodity prices and (ii) a sudden capital outflow.

\section{The stress test exercise in particular suffered from the previously mentioned} data limitations. Detailed data on the loan portfolio for some smaller banks was not available, forcing exclusion of the smaller banks from some stress tests. Individual bank data

\footnotetext{
${ }^{7}$ The test assumes all securities are held to maturity; it does not include any capital losses. The drop in CAR shown in Table 7 reflects a year's impact on the CAR of the drop in interest income (ceteris paribus). As the table shows, five of the large banks would become undercapitalized, requiring additional capital of 0.2 percent of GDP. If some liabilities (e.g., demand deposits) exhibit lower increases in rates, the drop in the CAR would be commensurately lower.

${ }^{8}$ Despite a recent decline in dollarization — driven mainly by slower depreciation of the Tanzanian shilling and lower inflation - 33 percent of deposits and 32 percent of loans remain in foreign currency, with a concentration in the larger banks: among the 10 largest, dollar deposits make up between 41.6 percent and 62.6 percent of total deposits.
} 
that was available suffered from inconsistencies and unexplained outliers affecting the results. The data weaknesses suggest a considerable need for caution in interpreting the stress testing results, which should be used primarily as a basis for further prudential investigation of the revealed vulnerabilities.

\section{B. Crisis Management Framework}

27. Important crisis management tools and components of a financial safety net are in place, but gaps remain and a comprehensive framework for crisis management is lacking. While there is a deposit insurance scheme and a regulatory framework for banking resolution, arrangements for emergency liquidity provision could be improved. Other key enhancements to preparedness for crisis management would include formal contingency plans, explicit institutional arrangements for cooperation among government agencies involved in crisis management, and regular crisis simulation exercises. Steps are being taken by the authorities to address these issues with technical assistance from the Fund.

28. The operational framework for the BOT's role as a liquidity provider to banks is adequate, but a framework for Emergency Liquidity Assistance (ELA) is yet to be developed. In day-to day operations, the BOT offers two lending facilities: (i) an intraday credit facility for payments system purposes and (ii) an overnight (Lombard) credit facility carrying a penalty interest rate (see Box 2 in section D). In both cases, borrowing is accessible for all commercial banks against pledged collateral in the form of short-term government securities. There are no explicit operational arrangements, however, for ELA beyond the day-to-day liquidity management framework and tools. The BOT should develop an operational framework for: (i) ELA in case of an acute liquidity problem in normal times (assistance to be given only to illiquid but solvent banks against adequate collateral);

(ii) ELA in a systemic crisis; and (iii) assistance to a critically undercapitalized but systemically important bank — including arrangements with the Ministry of Finance and Economic Affairs (MOFEA) in case of potential fiscal implications. The BOT should communicate these principles to the banks.

29. The framework for bank intervention and resolution appears adequate for a single bank failure, but a systemic crisis may require further arrangements. The secondary legislation that took effect in early 2009 provides the BOT with adequate authority to undertake enforcement action when a bank is facing financial difficulties or is operating in an unsound manner. It may give general or specific directions to a bank to affect its operations or the national interest, and the bank is required to comply. Possible prompt corrective actions in case of financial difficulties include monetary penalties, removal of personnel, appointment of a statutory manager, and license revocation. Private solutions (such as injection of capital by new or existing shareholders) are also considered. The framework for dealing with systemic crises may be enhanced, however, by making explicit logistical arrangements for communication and cooperation with the MOFEA and other 
supervisory agencies during a crisis, and allowing for more discretionary action to contain the crisis.

30. The new legal framework for deposit insurance adopted in 2006 is a welcome improvement, but additional measures would further enhance the safety net. In line with the 2003 FSAP recommendations, the Deposit Insurance Fund (DIF) has largely been confined to a pay-box (i.e., its role is restricted to repaying depositors in case of a bank failure), but the Deposit Insurance Board retains extended functions, such as liquidation responsibilities and participation in onsite examinations. Deposits (in domestic and foreign currency) are insured up to the equivalent of about US\$350, but interbank, government, and investment companies' deposits are excluded. The maximum coverage is low compared to neighboring countries, risking a deposit drain abroad when Tanzania liberalizes the capital account (see section III.B). While the recent initiative of the Board to triple coverage to the equivalent of about US\$1,000 is welcome, reserves are relatively small (less than 1 percent of banks' deposit liabilities) and the failure of a systemically important bank would overwhelm resources. It is recommended that reserves be strengthened (in part with the aid of the recent contribution increase) to enhance the DIF's ability to deal with the failure of a larger bank; a contingency plan with funding options (e.g., loans, public funds, or ex-post bank levy) for such an eventuality could also be helpful.

31. While important measures have been taken by the BOT to strengthen the dayto-day monitoring of global and domestic developments, it is recommended that a formal crisis management plan be adopted. The BOT has daily market monitoring meetings with senior management and a Financial Sector Stability Department has been established to coordinate work on financial sector stability and crisis management, including production of Financial Stability Reports. Beyond these measures, a formal crisis management plan would enhance crisis preparedness, and a crisis simulation exercise could identify weaknesses in present crisis management tools, in the coordination with other government agencies, and in the crisis communication strategy. The possibility of participating in cross-border contingency planning exercises should be explored.

\section{Banking Sector Regulation and Supervision}

32. The BCP Assessment undertaken in the context of the 2003 FSAP found that the framework of banking supervision was generally adequate, but that supervision needed to be put on a more risk-based footing. It was also recommended that transparency of banking supervision policies be enhanced and that the BOT be given independence from the government with respect to revocation of licenses and instituting corrective action. The crisis management framework and financial safety net needed strengthening.

\section{Substantial progress has been made in aligning the legislative framework} underpinning banking supervision to the BCP. It provides the BOT sufficient powers to discharge its mandate as the authority responsible for licensing, supervising and regulating 
the banking industry. Licensing is now the sole preserve of the BOT, removing the potential for political interference and review of licensing files indicates a detailed and thorough approach by the BOT. More recently, legislation has been supported by a suite of prudential regulations and guidelines. To improve offsite surveillance, all bank reporting to the BOT has been automated and is captured in the Banking Supervision Information System (BSIS).

34. In contrast, progress in enhancing operational aspects of supervision has been hampered by important capacity and organizational challenges. The Banking Supervision Department is operating with only half the authorized number of staff, while scarce resources continue to be consumed by activities marginal to supervision. Skill levels and additional skills absorption also present challenges, complicating the successive introduction of a CAMELS rating system (2005) and a risk-based supervision approach (2007). Important deficiencies exist in work processes, including lengthy clearance procedures for communication with banks and a failure to organize and safely store working papers completed in the course of inspections.

35. While substantial efforts have been made, the issues raised above leave BCPs compliance gaps (Appendix IV), despite a positive self-assessment carried out by the BOT. To promote full compliance with the BCPs, it is recommended that management consider the following measures:

- Address capacity and organizational challenges. In addition to training of existing staff, recruitment efforts should be stepped up as much as possible to fill authorized capacity with qualified staff with minimum required supervisory and financial analysis skills. Other organizational improvements, including reducing clearance requirements for communication with banks, are key. Work pressures should not be allowed to cause deterioration in orderly supervisory processes, including proper documentation, filing, and storage.

- Obtain hands-on technical assistance in the conduct of risk-based supervision to achieve full effectiveness of the BOT's risk-based framework.

- Increase cooperation with foreign regulators. Supervisory cooperation with EAC partner agencies appears strong and links are developing with another jurisdiction where Tanzanian banks operate. It is recommended that the BOT intensify cooperation with regulators of foreign bank subsidiaries operating in Tanzania and obtain an annual letter from "home" regulators confirming the parent bank's financial condition.

- Identify where correspondence between the BOT and banks may be entrusted to bank supervisors, without the need to obtain senior executive approval.

- Engage banks' senior management and their external auditors. In particular: 
- Require that senior management of a bank meet the BOT at least annually to present a full review of performance. Banks could also be required to submit a commentary on significant changes in prudential reporting figures at the time of submission. Regular tri-partite discussions with the bank's management and its auditors may also prove beneficial.

- Require that banks' external auditors provide certification that prudential reports have been prepared correctly and reflect the institution's records. This would eliminate the current practice whereby onsite examinations incorporate checking of prudential reports against the bank's general ledger.

- $\quad$ Eliminate the requirement that the opening of a new bank branch involves a physical inspection of (and report on) the premises by the BOT. This practice appears to add little value, but consumes scarce resources. The BOT has sufficient corrective powers if a bank is found, in the course of regular onsite inspections, to be conducting business in an unsafe manner.

\section{Systemic Liquidity Management}

36. The primary task of liquidity management in Tanzania is the sterilization of large liquidity injections resulting from government spending financed by direct budget support from donors. On average, Tanzania receives about 10 percent of GDP (or nearly US $\$ 2$ billion) a year in donor assistance, more than half of which is provided as direct budget support that is deposited directly into the government's account at the BOT (in Tanzanian shillings), while the FX counterpart is added to official international reserves. As the government expends these deposits, the resulting liquidity injection is mopped up by the BOT (Box 2).

37. In line with the 2003 FSAP recommendations, the use of liquidity management instruments was clarified to foster consistency in policy implementation. Operational changes in October 2007 led to a more balanced sterilization framework, with the BOT entering the FX market mostly on the sell side. Under the new policy, after calculating the sterilization needs for the month ahead, the BOT sells a proportional amount of FX on a daily basis. Additional interventions in the exchange market are limited to operations to smooth exchange rate movements (Figure 6). ${ }^{9}$

\footnotetext{
${ }^{9}$ In smoothing exchange rate movements, the BOT does not have any specific limits on daily changes in the exchange rate, but generally seeks to keep them within a range of \pm 1 percent.
} 


\section{Box 2. Monetary Policy Tools of the Bank of Tanzania}

The BOT has appropriate instruments available for withdrawing liquidity:

- $\quad$ SMRs - 10 percent on nongovernment deposits and 20 percent on government deposits (from January 2009), unremunerated, with averaging allowed over the previous 2-week fulfillment period. For banks with a sufficiently extensive branch network, the SMRs are reduced by 20 percent (following the exclusion from January 2009 of cash-in-vault for the SMRs calculation). The SMRs on FX deposits must be met in Tanzanian shillings.

- $\quad$ Liquidity paper (LP). Treasury bills (t-bills) of 35, 91, 182, and 364 days; auctions are held fortnightly. The BOT sets the auction sizes for LPs mainly to roll over outstanding LPs over time, in line with limited government domestic financing requirements, and to mop up liquidity as necessary in excess of FX sales. The interest cost of t-bills issued for monetary policy purposes is shared by the BOT, which reimburses the government for this cost, up to a yearly maximum of 15 percent of the BOT's gross earnings.

- $\quad$ Sales of FX by the BOT in the interbank FX market.

- $\quad$ REPOs (7- and 14-day maturities). REPO transactions are conducted through an auction process and take place on a daily basis to manage systemic liquidity between LP auctions.

- $\quad$ Standing facilities. The BOT offers a Lombard facility, with a rate based on 35-day t-bills, overnight and repo rates, whichever is higher, plus a 20 percent penalty. There is a limited set of eligible collateral, with a maximum of 91 days to maturity. In addition, t-bills and bonds can be rediscounted at a 500 basis point penalty rate. A deposit facility is also periodically offered by the BOT.

\section{The institutional framework for monetary policy decision-making appears} appropriate, and communication to the market has recently improved. The governor's monetary policy statement to parliament prior to the beginning of the fiscal year and the midyear policy review set out the broad monetary objectives for the year and the medium term. These are complemented by operational objectives set at monthly meetings of the Monetary Policy Committee. Weekly meetings of the Liquidity Management Committee, chaired by the governor, then set daily objectives for the week ahead, which are monitored and sometimes adjusted on a daily basis on a technical level, with approval by management. The recent initiative of the governor to meet monthly with chief executive officers (CEOs) of major banks about monetary policy implementation is a welcome improvement to the communication strategy. These technical meetings might be supplemented with less frequent high-level meetings about other strategic issues of interest to the banks. 
Figure 6. Tanzania: The Policy Mix, January 2006-December 2009

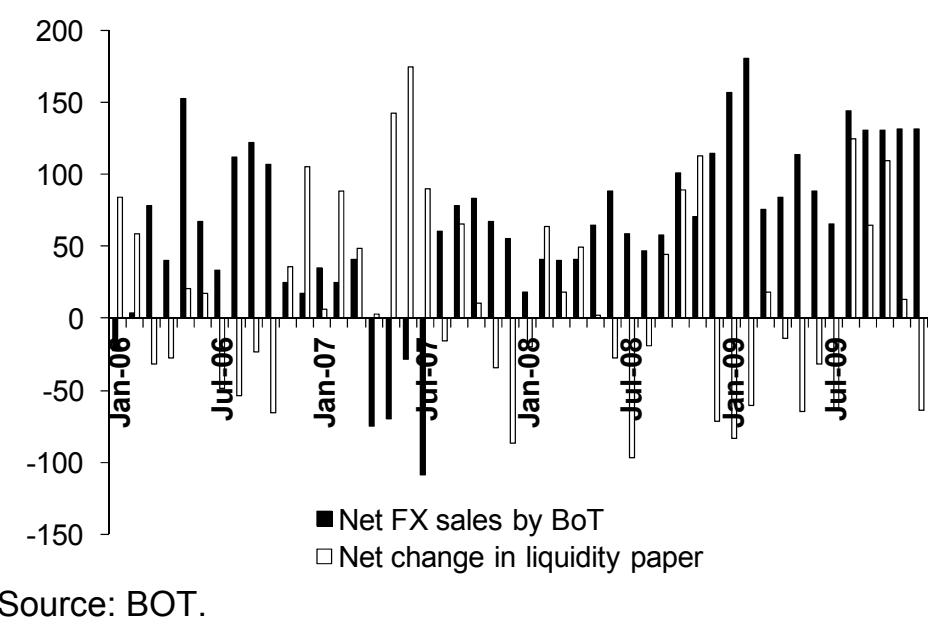

Figure 7. Tanzania: Money Market Transactions, January 2006-December 2009

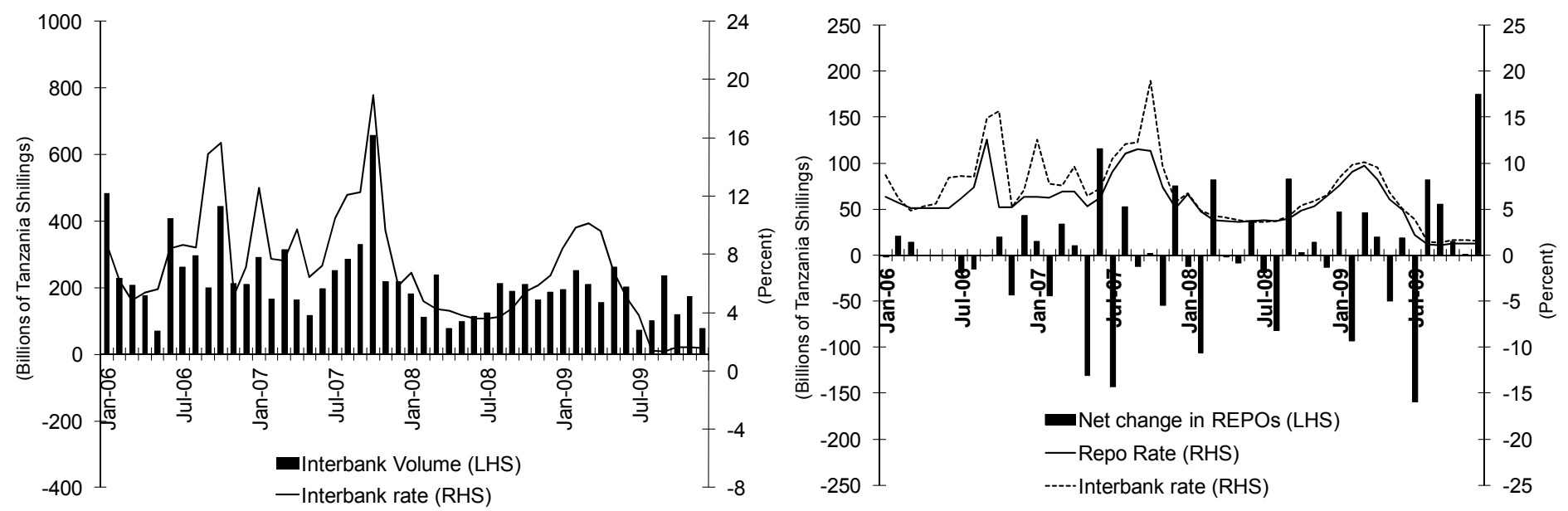

Source: BOT.

39. While the operational changes of October 2007 were designed to foster more stable conditions in the money market (Figure 7), implementation could be further improved to increase the transparency of policy intentions. Recommendations are the following:

- Distinguish clearly between sterilization and intervention objectives in procedures for selling $\boldsymbol{F X}$. Sterilization sales should be predictable and transparent to avoid undue exchange-rate effects, and it is recommended they be moved to an auction format. Intervention transactions should be designed to have maximum impact on the exchange rate; continuing the use of the interbank market is therefore appropriate. 
- Use the SMR only for long-term structural sterilization of liquidity, with frequent changes to be avoided. The recent move to allow averaging within the reserve fulfillment period is welcome.

- Use REPOs only for fine-tuning operations. Prolonged use of (reverse) REPOs can cause confusion about monetary policy intentions, suggesting that the often sizeable mopping up achieved is intended to be only temporary. More permanent instruments, such as FX sales or additional issuances of LP would be more appropriate, even if there is some impact on the shilling exchange rate or interest rates-indeed, such effects may be necessary to achieve the desired macroeconomic effects to underpin the sterilization effects.

- Improve further the consistency between the announced t-bill offering and actual sales and refrain from discretionary behavior at auctions. Currently, bids for t-bills may be rejected even though the full offering has not been met, while bids for some maturities are accepted beyond the volume offered. Occasionally, the BOT approaches banks after the auction to conduct additional sales of t-bills. This tends to reduce the clarity of policy intentions.

40. In addition, it is recommended that the authorities consider measures to improve further the accuracy of liquidity forecasts, which are the lynchpin of effective liquidity management:

- As government is the primary source of liquidity injections, advanced coordination between the MOFEA and BOT on planned major expenditures (as well as expected revenues) would help reduce forecasting errors. Specifically, cyclical patterns of expenditures (like monthly wage payments) and revenues (like end-month and endquarter tax payments) could be taken into account more effectively.

- $\quad$ Continued research into (excess) liquidity demand and monetary transmission mechanisms would enable the BOT to better align the supply of liquidity to demand patterns, helping to minimize the perceived need for banks to hold excess reserves and enhancing the functioning of the money market.

- $\quad$ Further analysis of forecasting errors may identify other sources of liquidity demand and supply that should be taken into account in the forecasting exercise.

\section{E. The Payments System}

41. Substantial progress has been made towards improving the payment systems infrastructure since 2003. With the implementation of the Tanzania Interbank Settlement System (TISS) in 2004, large-value and time-critical payments are now handled in real time. The Bank of Tanzania Act of 2006 gives the BOT broad powers to regulate the TISS and 
other payment systems. By 2010/11, the BOT plans to implement a national interbank switch that will promote efficiency and interoperability for point of sale (POS) and electronic funds transfers (EFT) transactions. It is recommended that the framework for the national switch at a minimum include (i) mandatory participation for banks that issue payment cards; (ii) regulation of the fee structure for automated teller machines (ATMs) and EFT/POS transactions; and, (iii) no restrictions for participation in other payment card systems.

42. Addressing remaining gaps in the payments system legislation is critical to enable the TISS participants to understand and manage credit and liquidity risks. The BOT currently has limited legal powers to develop regulations and enforce sanctions with respect to the TISS. The authorities should enact a National Payment Systems Act to provide a clear legal definition of "irrevocability of orders" and "finality" of payments in the TISS, and to make BOT regulations in this area legally enforceable.

\section{LONGER-TERM FINANCE}

\section{A. Capital Markets}

43. The Tanzanian capital market is still at a nascent stage and has not played a major role in resource mobilization and long-term financing of the economy. Only fifteen companies are listed on the DSE, with a market capitalization of US\$3.75 billion in February 2010 and a market turnover of US\$9.6 million in the fourth quarter of 2009 . The corporate bond market is very limited; as of February 2010 there were seven corporate bonds with an outstanding amount of US\$58.7 million. On the government bond market, secondary transactions are limited, but recent oversubscriptions on the 10-year primary bond auctions and increased placements indicate a growing appetite for long-term instruments by investors (Figure 8).

Figure 8. Tanzania: Yield Curve for Government Bonds and Volume of 10-Year Bonds

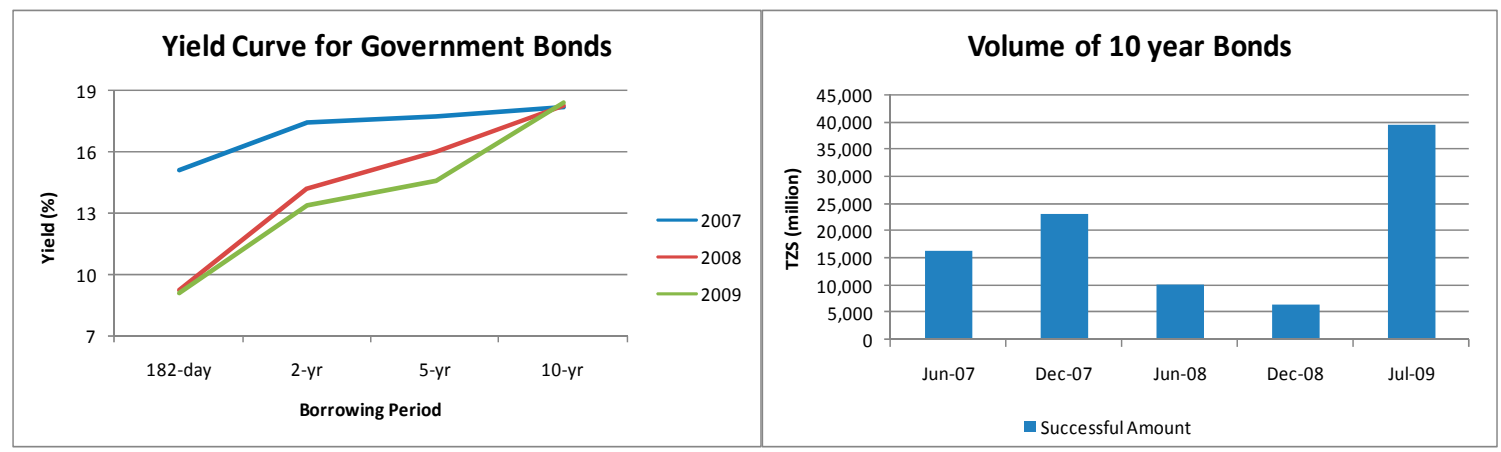

Source: BOT. 
44. The regionalization of the EAC capital market presents considerable opportunities for Tanzania. An EAC regional capital market (currently planned for implementation by 2012) will enable investors to diversify their portfolios, better manage risks, and grant issuers access to a deeper pool of long-term resources to finance their investments. It will generate economies of scale in market infrastructures and increased efficiency in securities transactions through the interconnection of exchanges, Central Securities Depositories (CSDs) and payment systems across borders in the EAC region.

45. Development of the securities markets (including through regionalization) also presents significant challenges. It is recommended that the authorities:

- Improve risk management for the settlement system. Settlement risk is currently significant and inhibits market development. Measures should include requiring guarantees by settlement banks of brokers' obligations; required initial and variation margin payments from settlement banks and the introduction of a guarantee fund.

- $\quad$ Strengthen the market legal and regulatory framework and pave the way for regional harmonization. Key priorities are to (i) adopt legislation requiring the demutualization of the DSE and the splitting of the DSE and the CSD into separate corporations; (ii) remove limitations on foreign investment in listed corporations; (iii) remove restrictions on foreign participation in the domestic government and corporate bond market; (iv) regulate over-the-counter (OTC) trade reporting and to allow OTC trading for bonds; (v) adopt regulations implementing common licensing standards for market intermediaries in the framework of the East African Member States Securities and Regulatory Authorities (EASRA); (vi) adopt regulations implementing common prudential standards for institutional investors, to be agreed in the framework of the EASRA; (vii) pass double-tax treaties with other partner states; and (viii) proceed with capital account liberalization (see below).

- $\quad$ Overhaul the Capital Markets and Securities Act to strengthen independence and confer adequate inspection and investigation powers on the Capital Markets and Securities Authority (CMSA) and to allow international information sharing. The CMSA should add to its staff total and should focus on meeting the IOSCO Principles. It should further enhance collaboration with counterpart regulatory authorities in other EAC partner states, including by (i) establishing a single certification for brokers operating in the EAC; and (ii) drafting a memorandum of understanding (MOU) with EAC's partner regulators that defines home-host supervisory responsibilities for capital market intermediaries, exchanges, CSDs, and institutional investors. 


\section{B. Capital Account Liberalization}

46. Capital account liberalization is key to the development of the regional capital market. As of now the Tanzanian capital account is substantially controlled. Residents' investments abroad and most inward capital transactions (except for FDI and some foreign loans) require the prior approval of the BOT and there is a general repatriation requirement for foreign currency receipts. Limits apply to the purchase of shares and corporate bonds on the DSE by nonresidents. The external use of the Tanzanian shilling is prohibited in most cases. These capital controls may have helped to mitigate the effect of the financial crisis on Tanzania, but they also introduce distortions, including a relatively low level of foreign investment in Tanzania and interference with the efficient allocation of resources and the development of financial markets.

47. In the context of the regional integration initiative, the BOT has developed a plan for the gradual lifting of capital controls by 2015. While the overall planned timeframe appears feasible, it is recommended that the liberalization plan be reviewed to ensure that the lifting of the controls is properly sequenced and coordinated with other supporting policies. It is recommended that implementation of the supporting measures explicitly be tied to the timeframe for completing capital account liberalization and the liberalization plan is kept under review to account for progress in establishing the prerequisites.

48. The authorities should consider liberalizing the capital account vis-à-vis all countries, not just regional partners. Since Uganda's capital account has already been liberalized, Rwanda plans to lift the controls soon, and Kenya has only a very limited number of controls in place, the opening of Tanzania's capital account within the EAC effectively implies capital account liberalization vis-à-vis all other countries. The absence of controls in other EAC countries does not allow the enforcement of the remaining controls in Tanzania towards third countries.

\section{Pensions and Insurance}

49. Tanzania's pension funds are significant purchasers of long-term financial instruments. The seven funds have approximately 800,000 members and funds under management in excess of T Sh 1,000 billion. The funds cover largely employees within the wider public sector. While membership is mandatory, coverage is low at 40 percent of the formal sector. The investment portfolios of these funds are undiversified and illiquid with a heavy weighting in long-term government securities and commercial real estate. Recent legal changes permit voluntary supplementary schemes, but none yet exist.

50. With the Social Security Regulatory Agency (SSRA) not yet operational, oversight is lacking; the supervisory function should be established without delay. The SSRA should be made operational as soon as possible, including by appointing a Board and a 
director general. The BOT and the SSRA should enter into a comprehensive MOU that defines the roles, responsibilities, functions, and activities of each agency; in the medium term, the authorities should review and amend the SSRA Act to address a number of significant deficiencies, including by clarifying the respective supervisory functions of the two agencies. In addition, it is recommended that separate laws for each pension fund be replaced by a single law and that existing inconsistencies with the SSRA Act be redressed.

51. Insurance companies are small and write mainly short-term business; the lifesegment is underdeveloped. The non-life market is dominated by four companies with an aggregate market share of 52 percent, with the remainder divided among twelve other institutions. The segment is small, with premiums of T Sh 191 billion and a penetration of 0.8 percent of GDP, derived mainly from motor, property and marine businesses. The life segment is underdeveloped with written premium of T Sh 18 billion and insurance penetration of 0.1 percent. Four companies operate in this segment of the market. The government-owned National Insurance Corporation (NIC) has suffered a sharp decline in

market share in both markets due to loss in confidence reflecting its inability to pay claims.

\section{A number of reforms to the insurance market are recommended:}

- A further increase in the minimum capital requirement for all types of insurers to US\$5 million, beyond the currently planned gradual increase to US\$1 million.

- $\quad$ Adoption of minimum disclosure requirements (including for fees and commissions) for insurance brokers, which generate an estimated 60 percent of gross premiums.

- Short-term resolution of the NIC. The long-standing inability to pay claims of NIC (already noted in the 2003 FSAP) continues to impact confidence and the development of the insurance market.

- $\quad$ Finalization of arrangements to allow bancassurance, which will improve the distribution channels in the market. 


\section{Table 1. Tanzania: Selected Economic and Financial Indicators (2006/07-2011/12)}

\begin{tabular}{|c|c|c|c|c|c|c|c|}
\hline \multirow[t]{2}{*}{. } & \multirow[t]{2}{*}{$2007 / 08$} & \multirow[t]{2}{*}{ 2008/09 } & \multicolumn{2}{|c|}{$2009 / 10$} & \multirow{2}{*}{$\begin{array}{r}\text { 2010/11 } \\
\text { Proj. }\end{array}$} & \multirow{2}{*}{$\begin{array}{r}2011 / 12 \\
\text { Proj. }\end{array}$} & \multirow{2}{*}{$\begin{array}{r}\text { 2012/13 } \\
\text { Proj. }\end{array}$} \\
\hline & & & Prog. $^{5}$ & Proj. & & & \\
\hline & \multicolumn{7}{|c|}{ (Annual percentage change, unless otherwise indicated) } \\
\hline \multicolumn{8}{|l|}{ National income and prices } \\
\hline Real GDP growth (calendar year) ${ }^{1}$ & 7.1 & 7.4 & 5.0 & 5.5 & 6.2 & 6.7 & 7.5 \\
\hline Real GDP growth (fiscal year) & 7.3 & 6.4 & 5.5 & 5.8 & 6.5 & 7.1 & 7.5 \\
\hline Consumer prices (period average) & 8.4 & 11.8 & $8.0-9.0$ & 10.6 & 5.8 & 5.0 & 5.0 \\
\hline Consumer prices (end of period) & 9.3 & 10.7 & $6.0-8.0$ & 8.0 & 5.0 & 5.0 & 5.0 \\
\hline \multicolumn{8}{|l|}{ External sector } \\
\hline Export, f.o.b (in millions of U.S. dollars) & 2,609 & 2,969 & 3,154 & 3,216 & 3,826 & 4,168 & 4,565 \\
\hline Imports, f.o.b. (in millions of U.S. dollars) & $-5,667$ & $-5,970$ & $-6,070$ & $-6,149$ & $-6,996$ & $-7,539$ & $-8,045$ \\
\hline Export volume & 6.2 & 5.3 & 6.2 & 6.6 & 10.3 & 9.8 & 8.4 \\
\hline Import volume & 13.3 & -1.5 & 8.9 & 6.0 & 6.4 & 5.6 & 4.3 \\
\hline Terms of trade & -7.7 & 10.9 & 7.7 & 8.2 & -2.6 & -2.7 & -1.2 \\
\hline Nominal effective exchange rate (end of period; depreciation -) & 1.8 & -3.4 & $\ldots$ & $\ldots$ & $\ldots$ & $\ldots$ & $\ldots$ \\
\hline Real effective exchange rate (end of period; depreciation -) & 2.9 & 6.4 & $\ldots$ & $\ldots$ & $\ldots$ & $\ldots$ & $\ldots$ \\
\hline \multicolumn{8}{|l|}{ Money and credit ${ }^{2}$} \\
\hline Broad money (M3) & 18.1 & 19.0 & 21.1 & 21.6 & 21.0 & $\ldots$ & $\ldots$ \\
\hline Net foreign assets & 4.7 & 15.7 & -5.2 & 13.1 & 13.4 & $\ldots$ & $\ldots$ \\
\hline Net domestic assets & 39.8 & 23.0 & 51.2 & 31.2 & 28.5 & $\ldots$ & $\ldots$ \\
\hline Credit to nongovernment sector & 32.9 & 33.6 & 33.6 & 14.5 & 21.3 & $\ldots$ & $\ldots$ \\
\hline Velocity of money (GDP/M3; average) & 3.7 & 3.7 & 3.5 & 3.3 & 3.3 & $\ldots$ & $\ldots$ \\
\hline Treasury bill interest rate (in percent; end of period) $)^{3}$ & 8.2 & 7.5 & $\cdots$ & 6.3 & $\ldots$ & $\ldots$ & $\cdots$ \\
\hline & \multicolumn{7}{|c|}{ (Percent of GDP) } \\
\hline Public Finance & & & & & & & \\
\hline Revenue (excluding grants) & 15.9 & 15.8 & 16.5 & 15.8 & 16.3 & 16.6 & 16.9 \\
\hline Total grants & 6.9 & 4.9 & 6.2 & 6.3 & 4.9 & 4.6 & 4.3 \\
\hline Expenditure (including adjustment to cash) & 24.4 & 25.2 & 28.5 & 27.7 & 27.1 & 26.5 & 25.8 \\
\hline Overall balance (excluding grants) & -8.5 & -9.4 & -11.9 & -12.0 & -10.8 & -10.0 & -8.9 \\
\hline Domestic financing & -1.5 & 1.0 & 1.6 & 1.6 & 1.0 & 1.0 & 1.0 \\
\hline Stock of domestic debt (end of period) & 13.4 & 12.0 & 12.0 & 11.9 & 11.7 & 11.4 & 11.1 \\
\hline \multicolumn{8}{|l|}{ Savings and investment ${ }^{1}$} \\
\hline Resource gap & -16.9 & -13.7 & -12.2 & -12.1 & -11.3 & -11.2 & -10.7 \\
\hline Investment & 29.6 & 29.8 & 28.4 & 27.8 & 28.0 & 28.6 & 28.9 \\
\hline Government & 9.7 & 10.0 & 10.4 & 10.3 & 10.6 & 10.3 & 9.5 \\
\hline Nongovernment ${ }^{4}$ & 20.0 & 19.8 & 18.0 & 17.5 & 17.4 & 18.4 & 19.5 \\
\hline Gross domestic savings & 12.8 & 16.2 & 16.2 & 15.7 & 16.7 & 17.4 & 18.3 \\
\hline \multicolumn{8}{|l|}{ External sector } \\
\hline Current account balance (excluding current transfers) & -14.1 & -13.1 & -11.6 & -11.5 & -11.7 & -11.7 & -11.1 \\
\hline Current account balance (including current transfers) & -10.6 & -9.8 & -8.6 & -8.3 & -9.3 & -9.4 & -9.0 \\
\hline & \multicolumn{7}{|c|}{ (Millions of U.S. dollars, unless otherwise indicated) } \\
\hline \multicolumn{8}{|l|}{ Balance of payments } \\
\hline Current account balance (excluding current transfers; deficit -) & $-2,675$ & $-2,804$ & $-2,760$ & $-2,695$ & $-2,998$ & $-3,244$ & $-3,388$ \\
\hline Gross official reserves & 2,660 & 2,925 & 3,277 & 3,461 & 3,755 & 4,085 & 4,365 \\
\hline In months of imports of goods and nonfactor services (current ys & 4.5 & 4.6 & 5.1 & 5.2 & 5.0 & 5.0 & 5.0 \\
\hline External debt (percent of GDP) & 24.9 & 25.6 & 25.3 & 26.6 & 29.5 & 32.0 & 33.6 \\
\hline
\end{tabular}

Sources: Tanzanian authorities; and Fund staff estimates and projections.

${ }^{1}$ Data are on calendar year basis. For example, 2006/07 data are for calendar year 2006.

${ }^{2}$ Figures for 2008/09 onward reflect a new series based on the Fund's 2000 Monetary and Financial Statistics Manual .

${ }^{3}$ End-year (June) monthly weighted-average yield of 35-, 91-, 182-, and 364-day treasury bills. For 2009/10, figure is for February 2010.

${ }^{4}$ Including change in stocks.

${ }^{5}$ From the sixth review under the PSI, based on previous GDP projection. 
Table 2. Tanzania: Financial System Structure, 2006-09

\begin{tabular}{|c|c|c|c|c|c|c|c|c|c|c|c|c|}
\hline & \multicolumn{3}{|c|}{ Dec-06 } & \multicolumn{3}{|c|}{ Dec-07 } & \multicolumn{3}{|c|}{ Dec-08 } & \multicolumn{3}{|c|}{ Dec-09 } \\
\hline & \multirow[t]{2}{*}{ Number } & \multicolumn{2}{|c|}{ Total Assets Percent of GDP } & \multirow[t]{2}{*}{ Number } & \multicolumn{2}{|c|}{ Total Assets Percent of GDP } & \multirow[t]{2}{*}{ Number } & \multicolumn{2}{|c|}{ Total Assets Percent of GDP } & \multirow[t]{2}{*}{ Number } & \multicolumn{2}{|c|}{ Total Assets Percent of GDP } \\
\hline & & [TSh bln] & & & [TSh bln] & & & [TSh bln] & & & [TSh bln] & \\
\hline & & & & & & & & & & & & \\
\hline \multicolumn{13}{|l|}{ Universal and commercial Banks } \\
\hline Large domestic banks $1 /$ & 3 & 2,505 & 14.0 & 3 & 3,262 & 15.6 & 3 & 3,986 & 16.1 & 3 & 4,821 & 16.4 \\
\hline Major international banks $2 /$ & 4 & 2,054 & 11.4 & 4 & 2,098 & 10.0 & 4 & 2,308 & 9.3 & 4 & 2,849 & 9.7 \\
\hline Other banks & 18 & 791 & 4.4 & 19 & 1,624 & 7.8 & 21 & 2,072 & 8.4 & 26 & 2,262 & 7.7 \\
\hline & & & & & & & & & & & & \\
\hline & & & & & & & & & & & & \\
\hline \multicolumn{13}{|l|}{ Private banks } \\
\hline Domestic & 8 & 2,160 & 12.0 & 9 & 2,964 & 14.2 & 9 & 3,732 & 15.1 & 13 & 4,666 & 15.9 \\
\hline Foreign & 13 & 2,979 & 16.6 & 13 & 3,748 & 17.9 & 15 & 4,343 & 17.5 & 16 & 4,924 & 16.8 \\
\hline State-ow ned banks & 4 & 211 & 1.2 & 4 & 272 & 1.3 & 4 & 292 & 1.2 & 4 & 343 & 1.2 \\
\hline Other depository institutions $3 /$ & 7 & 47 & 0.3 & 7 & 58 & 0.3 & 8 & 77 & 0.3 & 8 & 106 & 0.4 \\
\hline & & & & & & & & & & & & \\
\hline \multicolumn{13}{|l|}{ Nonbank Financial Institutions } \\
\hline Insurance companies & 16 & 184 & 1.0 & 18 & 212 & 1.0 & 18 & 294 & 1.2 & 23 & 297 & 1.0 \\
\hline Pension funds 4/ & 4 & 535 & 3.0 & 4 & 660 & 3.1 & 4 & 826 & 3.3 & 6 & 2,736 & 9.3 \\
\hline Collective investment schemes 5 / & 3 & 130 & 0.7 & 4 & 77 & 0.4 & 4 & 119 & 0.5 & $\ldots$ & $\ldots$ & $\ldots$ \\
\hline & & & & & & & & & & & & \\
\hline Total financial system & & 6,245 & 34.8 & & 7,991 & 38.1 & & 9,681 & 39.1 & & 13,070 & 44.5 \\
\hline & & & & & & & & & & & & \\
\hline \multicolumn{13}{|l|}{ Memorandum items } \\
\hline GDP & & 17,941 & & & 20,948 & & & 24,754 & & & 29,376 & \\
\hline & & & & & & & & & & & & \\
\hline \multicolumn{13}{|l|}{ Notes: } \\
\hline \multicolumn{13}{|l|}{ 1/ NBC, NMB and CRDB } \\
\hline \multicolumn{13}{|c|}{ 2/ Citibank, Standard Chartered, Stanbic, and Barclays } \\
\hline \multicolumn{13}{|c|}{ 3/ Rural and cooperative banks, as defined under the banking and Financial Institutions Act, 2006} \\
\hline \multicolumn{13}{|l|}{ 4/ PPF, LAPF, GEPF, ZSSF } \\
\hline 5/ Money market mutual funds & & & & & & & & & & & & \\
\hline
\end{tabular}

Source: BOT. 
Table 3.Tanzania: Selected Financial Soundness Indicators, 2006-09

\begin{tabular}{|c|c|c|c|c|c|c|c|}
\hline & 2006 & 2007 & 2008 & Mar-09 & Jun-09 & Sep-09 & Dec-09 \\
\hline \multicolumn{8}{|l|}{ Capital adequacy } \\
\hline Regulatory Tier I capital to risk-weighted assets & 15.5 & 15.8 & 14.5 & 20.5 & 18.4 & 19.3 & 18.1 \\
\hline Regulatory Tier I+II capital to risk-weighted assets & 16.3 & 16.2 & 14.9 & 21.2 & 18.8 & 19.7 & 18.5 \\
\hline Regulatory capital to total assets & 7.6 & 8.1 & 8.8 & 12.2 & 10.6 & 11.0 & 11.1 \\
\hline \multicolumn{8}{|l|}{ Asset quality } \\
\hline Nonperforming loans (net of provisions) to gross loans & 6.8 & 6.3 & 6.2 & 7.4 & 7.8 & 6.4 & 6.7 \\
\hline $\begin{array}{l}\text { Nonperforming loans (net of provisions) to total capital } \\
\text { Sectoral distribution of loans }\end{array}$ & 21.1 & 22.0 & 25.2 & 22.4 & 25.8 & 17.8 & 17.3 \\
\hline Agriculture & 9.0 & 11.9 & 10.4 & 10.6 & 11.1 & 12.3 & 10.4 \\
\hline Personal loans & $\ldots$ & $\ldots$ & $\ldots$ & 13.8 & 13.7 & 11.3 & 12.1 \\
\hline Mining and manufacturing & 18.3 & 20.3 & 14.7 & 21.5 & 20.9 & 20.4 & 21.7 \\
\hline Tourism, hotels, restaurants & & $\ldots$ & $\ldots$ & 4.6 & 4.8 & 4.4 & 4.4 \\
\hline Trade & 15.2 & 17.0 & 18.5 & 17.5 & 17.8 & 18.5 & 19.0 \\
\hline Transport and communication & 7.9 & 6.9 & 7.2 & 7.5 & 10.1 & 9.7 & 9.3 \\
\hline Construction and property & 5.0 & 5.1 & 4.9 & 4.8 & 4.6 & 5.1 & 5.1 \\
\hline Other & 44.6 & 38.8 & 44.3 & 19.6 & 17.1 & 18.3 & 18.1 \\
\hline \multicolumn{8}{|l|}{ Earnings and profitability } \\
\hline Return on assets & 3.9 & 4.7 & 3.8 & 4.0 & 3.6 & 3.4 & 3.2 \\
\hline Return on equity & 26.7 & 29.0 & 23.2 & 24.2 & 21.2 & 20.7 & 18.4 \\
\hline Net interest income to gross income & 53.2 & 53.8 & 55.0 & 69.9 & 52.3 & 51.4 & 51.4 \\
\hline Non interest expenses to gross income & 43.5 & 42.5 & 48.8 & 44.6 & 45.3 & 46.6 & 47.6 \\
\hline Personnel expenses to noninterest expenses & 39.5 & 40.5 & 40.6 & 44.6 & 45.2 & 43.7 & 42.6 \\
\hline Trading and fee income to total income & 27.1 & 25.7 & 26.0 & 29.9 & 26.5 & 29.1 & 29.6 \\
\hline \multicolumn{8}{|l|}{ Liquidity } \\
\hline Liquid assets / total assets & 48.6 & 48.0 & 37.6 & 36.6 & 37.8 & 41.1 & 40.6 \\
\hline Liquid assets to short term liabilities & 54.2 & 53.0 & 41.7 & 43.7 & 45.2 & 48.5 & 46.5 \\
\hline Total (non-bank) loans to customer deposits & 50.0 & 57.8 & 68.5 & 66.1 & 64.8 & 60.7 & 60.8 \\
\hline \multicolumn{8}{|l|}{ Sensitivity to market risk } \\
\hline Net open position in foreign exchange to capital & -49.0 & -70.5 & -39.9 & -14.0 & -5.9 & -18.8 & -11.5 \\
\hline
\end{tabular}

Source: BOT. 
Table 4. Tanzania: Compliance with Prudential Limits, end-December 2009

\begin{tabular}{|c|c|c|}
\hline $\begin{array}{l}\text { Main Prudential } \\
\text { Limits }\end{array}$ & Description & $\begin{array}{l}\text { Number of Banks } \\
\text { Noncompliant }\end{array}$ \\
\hline Reserve requirement & $\begin{array}{l}10 \text { percent of nongovernment deposits plus } \\
20 \text { percent of government deposits. }\end{array}$ & None \\
\hline Capital adequacy & $\begin{array}{l}\text { Tier 1: } 10 \text { percent of risk-weighted assets. } \\
\text { Tier 2: } 12 \text { percent of risk-weighted assets. }\end{array}$ & $\begin{array}{l}\text { Tier } 1: 2 \\
\text { Tier 2: } 4\end{array}$ \\
\hline $\begin{array}{l}\text { Single borrower } \\
\text { exposure }\end{array}$ & $\begin{array}{l}\text { Exposure not to exceed } 25 \text { percent of capital. } \\
\text { Exposures with government guarantees may } \\
\text { receive a waiver from BOT }\end{array}$ & $\begin{array}{l}\text { None (after waivers for } \\
\text { government } \\
\text { guarantees) }\end{array}$ \\
\hline $\begin{array}{l}\text { Placement of funds in } \\
\text { foreign banks abroad }\end{array}$ & $\begin{array}{l}\text { Maximum } 60 \text { percent of total placement for } A \text { rated } \\
\text { bank } \\
\text { Maximum } 40 \text { percent of total placement for B rated } \\
\text { bank. } \\
\text { Maximum } 20 \text { percent of total placement for non- } \\
\text { rated foreign bank. }\end{array}$ & 4 \\
\hline $\begin{array}{l}\text { Net open position in } \\
\text { FX }\end{array}$ & Not to exceed 20 percent of core capital. & $\begin{array}{l}4 \text { for the week ending } \\
12 / 31 / 09^{11}\end{array}$ \\
\hline Liquid asset ratio & $\begin{array}{l}\text { Liquid assets not to be less than } 20 \text { percent of } \\
\text { demand liabilities. }\end{array}$ & None \\
\hline Loan to deposit ratio & $\begin{array}{l}\text { Gross loan portfolio not to exceed } 80 \text { percent of its } \\
\text { total deposit liabilities. }\end{array}$ & $\begin{array}{l}8 \text { (Most with BOT } \\
\text { waiver) }\end{array}$ \\
\hline
\end{tabular}

Source: BOT.

\footnotetext{
${ }^{10}$ According to BOT. The mission was unable to verify the validity of these waivers with data on guarantees obtained by the mission.

${ }^{11}$ A new method for computing the net open position was introduced on December 31, 2009 and a waiver was given to noncompliant banks during a transition period.
} 
Table 5. Tanzania: Adequacy of Loan Loss Provisions, December 2009

Number of banks not adequately provisioned

Of which: systemically important ${ }^{12}$

Additional provisioning required

T. Sh. billion

13.0

Percent of Tier I capital

Number of banks undercapitalized after additional provisioning

Average CAR

8.2

Number of systemically important banks undercapitalized after additional provisioning

Average CAR

9.5

Additional capital injection required

T. Sh. billion

5.0

Percent of Tier I capital

0.5

Source: BOT and IMF staff estimates.

\footnotetext{
${ }^{12}$ Largest 8 banks measured by asset size.
} 
Table 6. Tanzania: Stress Test Results-Default of Three Largest Borrowers

\begin{tabular}{|c|c|c|c|c|c|c|c|c|}
\hline & \multirow[t]{2}{*}{$\begin{array}{l}\text { CAR } \\
\text { after } \\
\text { shock }\end{array}$} & \multirow[t]{2}{*}{$\begin{array}{l}\text { Change from } \\
\text { Baseline }\end{array}$} & \multicolumn{2}{|c|}{$\begin{array}{l}\text { Undercapitalized banks } \\
\quad(\text { CAR < 12) }\end{array}$} & \multicolumn{2}{|c|}{$\begin{array}{l}\text { Insolvent Banks } \\
\quad \text { CAR<0 }\end{array}$} & \multicolumn{2}{|c|}{$\begin{array}{l}\text { Recapitalization } \\
\text { Costs }\end{array}$} \\
\hline & & & Number & $\begin{array}{l}\% \text { of total } \\
\text { assets }\end{array}$ & Number & $\begin{array}{c}\% \text { of total } \\
\text { assets }\end{array}$ & $\begin{array}{c}\text { T Sh } \\
\text { millions }\end{array}$ & $\begin{array}{l}\text { Percent } \\
\text { of GDP }\end{array}$ \\
\hline Failure of the first largest exposure & 11.8 & -6.6 & $\begin{array}{c}5 \text { (Banks: } 1 \\
4,5,7,9)\end{array}$ & 39.3 & $\begin{array}{l}1 \text { (Banks: } \\
9 \text { ) }\end{array}$ & 1.48 & 55,346 & 0.19 \\
\hline Failure of the two largest exposures & 7.6 & -10.8 & $\begin{array}{l}8 \text { (all banks } \\
\text { except bank } \\
2 \text { ) }\end{array}$ & 74.3 & $\begin{array}{l}2 \text { (Banks: } \\
5,9)\end{array}$ & 10.8 & 167,278 & 0.57 \\
\hline
\end{tabular}

Source: BOT. 
Table 7. Tanzania: Summary of Stress Test Results

\begin{tabular}{|c|c|c|c|c|c|c|c|c|c|c|}
\hline & \multicolumn{6}{|c|}{ All banks } & \multicolumn{2}{|c|}{ Domestic banks } & \multicolumn{2}{|c|}{ Foreign owned } \\
\hline & \multirow[t]{2}{*}{$\begin{array}{l}\text { Aggregate } \\
\text { CAR }\end{array}$} & \multirow[t]{2}{*}{$\begin{array}{l}\text { Change } \\
\text { in CAR }\end{array}$} & \multicolumn{2}{|c|}{ Undercapitalized banks (CAR <12) } & \multicolumn{2}{|c|}{$\begin{array}{l}\text { Recapitalization } \\
\text { need }\end{array}$} & \multirow[t]{2}{*}{ CAR } & \multirow[t]{2}{*}{$\begin{array}{l}\text { change } \\
\text { in CAR }\end{array}$} & \multirow[t]{2}{*}{ CAR } & \multirow[t]{2}{*}{$\begin{array}{l}\text { change } \\
\text { in CAR }\end{array}$} \\
\hline & & & Number $1 /$ & $\begin{array}{c}\% \text { of total } \\
\text { bank assets }\end{array}$ & TZS bn. & $\begin{array}{l}\% \text { of } \\
\text { GDP }\end{array}$ & & & & \\
\hline \multicolumn{11}{|l|}{ A. Single factor shocks } \\
\hline \multicolumn{11}{|l|}{35 banks } \\
\hline Baseline & 20,0 & - & 3 (Banks: 11, 33, 34) & 2,9 & 3.4 & 0,0 & 20,7 & - & 19,6 & - \\
\hline \multicolumn{11}{|l|}{ Credit risk } \\
\hline Increase in NPLs (by 45\%) & 18,4 & $-1,6$ & 5 (Banks: 9, 11, 21, 33, 34) & 5,7 & 6.6 & 0,0 & 18,5 & $-2,2$ & 18,7 & $-0,9$ \\
\hline $\begin{array}{l}\text { Increase in provisions (up to } \min .50 \% \\
\text { of NPLs) }\end{array}$ & 16,8 & $-3,2$ & 5 (Banks: 5, 9, 11, 33, 34) & 13,7 & 9.5 & 0,0 & 16,7 & -4 & 18,1 & $-1,5$ \\
\hline \multicolumn{11}{|l|}{ Exchange rate risk } \\
\hline Depreciation of TZS against USD (30\%) & 19,5 & $-0,5$ & 5 (Banks: 5, 11, 17, 33, 34) & 13,4 & 12.5 & 0,0 & 20 & $-0,7$ & 19 & $-0,6$ \\
\hline Appreciation of TZS against USD (30\%) & 19,8 & $-0,2$ & 4 (Banks: 11, 21, 33, 34) & 4,2 & 4.9 & 0,0 & 21 & 0,3 & 19 & $-0,6$ \\
\hline \multicolumn{11}{|l|}{10 largest banks } \\
\hline Baseline & 18,5 & - & 0 & - & - & - & 19,5 & - & 17,8 & - \\
\hline \multicolumn{11}{|l|}{ Interest rate risk } \\
\hline $\begin{array}{l}\text { Increase in interest rates by } 574 \text { b.p. } \\
\text { (short and long term) }\end{array}$ & 17,9 & $-0,6$ & 0 & - & - & - & 19,3 & $-0,2$ & 16,8 & -1 \\
\hline $\begin{array}{l}\text { Increase in interest rates by } 1839 \text { b.p. } \\
\text { (short term) and } 574 \text { b.p. (long term) }\end{array}$ & 15,2 & $-3,3$ & 5 (Banks: 1, 3, 5, 7, 8) & 51,0 & 42.7 & 0,2 & 17 & $-2,5$ & 13,8 & -4 \\
\hline \multicolumn{11}{|c|}{ B. Adverse macroeconomic scenarios (10 largest banks) } \\
\hline Baseline & 18,5 & & 0 & 0 & - & - & 19,5 & - & 17,8 & - \\
\hline \multicolumn{11}{|l|}{ Scenario 1 - drop in commodity prices } \\
\hline Q3 2009 & 17,0 & $-1,5$ & 2 (Banks: 5, 9) & 10,8 & 33.4 & 0,1 & 19,2 & $-0,3$ & 15,1 & $-2,7$ \\
\hline Q2 2010 & 15,6 & $-2,9$ & 3 (Banks: 5, 8, 9) & 16,3 & 53.4 & 0,2 & 17,7 & $-1,8$ & 14 & $-3,8$ \\
\hline Q2 2011 & 15,1 & $-3,4$ & 3 (Banks: 5, 8, 9) & 16,3 & 61.6 & 0,2 & 17 & $-2,5$ & 13,6 & $-4,2$ \\
\hline Scenario 2 - sudden capital outflow & 14,5 & $-4,0$ & 4 (Banks: 1, 5, 8, 9) & 21,7 & 40.1 & 0,1 & 16,3 & $-3,2$ & 13,1 & $-4,7$ \\
\hline
\end{tabular}

Source: IMF staff estimates.

Notes:

1/ Banks 1-5: large foreign banks; banks 6-8: large domestic banks; banks 9-25: medium and small-sized commercial banks; banks 26-34: community banks. 
Table 8. Tanzania: Liquidity Stress Test Results

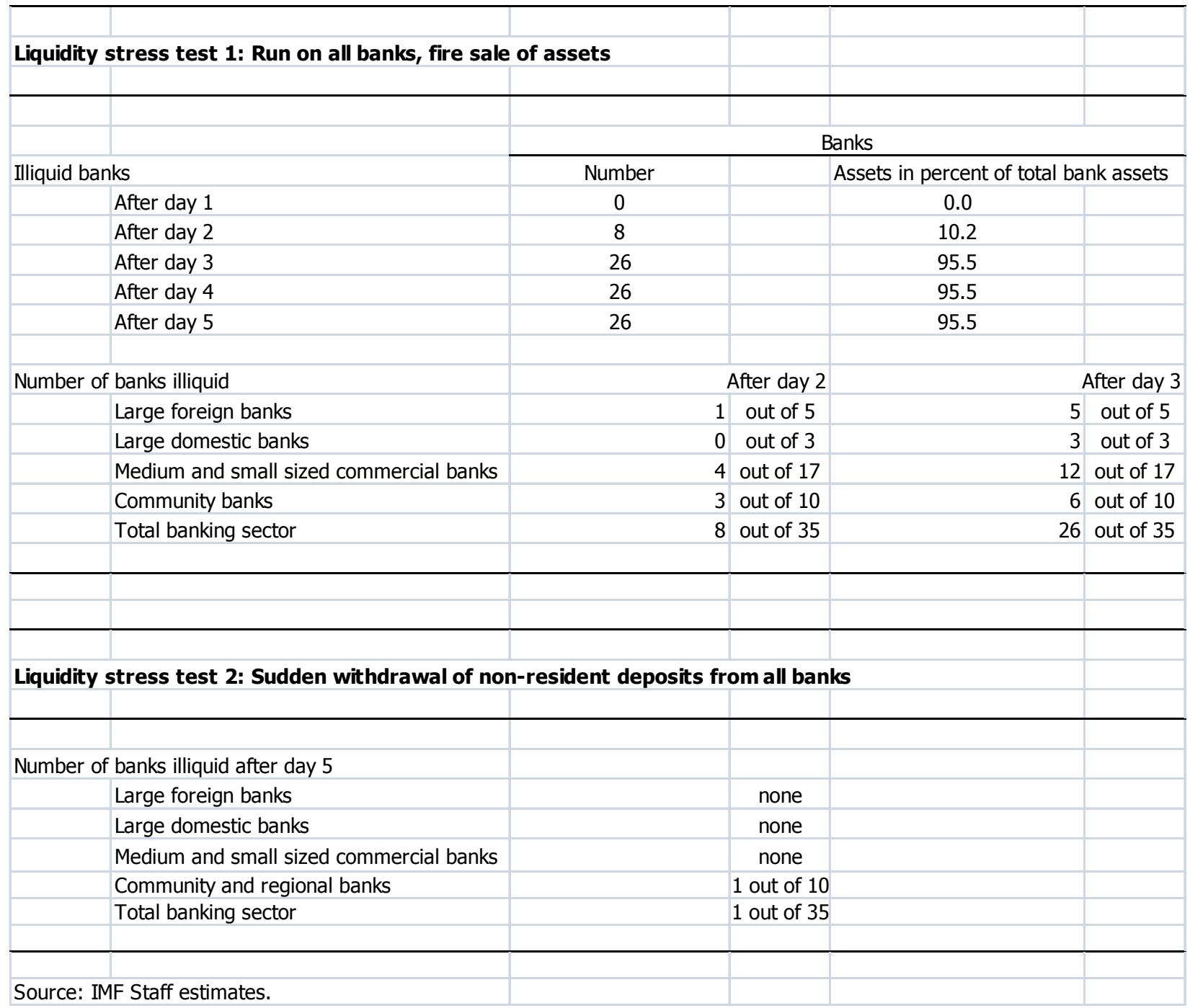




\section{APPENDIX I. DETAILED SUMMARY OF RECOMMENDATIONS 1/}

\begin{tabular}{|c|c|c|}
\hline & Recommendations & Timeframe /2 \\
\hline \multicolumn{3}{|l|}{ Financial Structure } \\
\hline $\begin{array}{l}\text { Structure and } \\
\text { Efficiency of the } \\
\text { Banking System }\end{array}$ & $\begin{array}{l}\text { 1. Explore the pros and cons of raising minimum capital requirements to promote consolidation of small- } \\
\text { and medium-sized banks to contest the top tier. } \\
\text { 2. Abolish loan to deposit ceiling (currently } 80 \text { percent). } \\
\text { 3. Remove restriction on the number of foreign banking employees to narrow skills gap. }\end{array}$ & $\begin{array}{l}M \\
S \\
S\end{array}$ \\
\hline $\begin{array}{l}\text { Credit Information } \\
\text { and Creditor } \\
\text { Rights }\end{array}$ & $\begin{array}{l}\text { 4. Pass regulations for Credit Bureau; create the database for credit information and identification of } \\
\text { debtors. } \\
\text { 5. Introduce adequate tax treatment of leasing contracts. } \\
\text { 6. Design and implement a comprehensive reform of civil procedure, to reduce the interference caused by } \\
\text { the use of delaying tactics by debtors. } \\
\text { 7. Grant exclusive jurisdiction over credit enforcement to the commercial courts. } \\
\text { 8. Accelerate the formalization process for land titles. } \\
\text { 9. Eliminate the consent of the Commissioner for Land and the endorsement of valuation by the Chief } \\
\text { Valuer for the creation of security interests over land. } \\
\text { 10. Computerize land and company registries. } \\
\text { 11. Reform of the appeal process, limiting the number of available appeals and restricting the suspension } \\
\text { effect of appeals over credit enforcement. } \\
\text { 12. Eliminate the priority of tax over secured credit. } \\
\text { 13. Pass the insolvency regulations for the Companies Act } 2002 \text {. } \\
\text { 14. Implement judicial reform programs, with continuing education for judges, computerization of } \\
\text { proceedings, case recording and case management. }\end{array}$ & $\begin{array}{l}M \\
M \\
M \\
M \\
M \\
M \\
M \\
M \\
M \\
M\end{array}$ \\
\hline \multicolumn{3}{|c|}{ Safeguarding Financial Stability } \\
\hline $\begin{array}{l}\text { Risks and } \\
\text { Vulnerabilities in } \\
\text { Banking System }\end{array}$ & $\begin{array}{l}\text { 15. Improve timeliness and quality of prudential data; establish consistent data set for macroprudential } \\
\text { analysis. } \\
\text { 16. Be more proactive in ensuring compliance with main prudential limits, including on provisioning and } \\
\text { large exposures. } \\
\text { 17. Build up capacity for risk analysis and implement improved risk management tools. }\end{array}$ & $\begin{array}{l}\text { S } \\
\text { S } \\
M\end{array}$ \\
\hline $\begin{array}{l}\text { Crisis } \\
\text { Management } \\
\text { Framework }\end{array}$ & $\begin{array}{l}\text { 18. Establish framework for emergency liquidity assistance that would go beyond the day-to-day liquidity } \\
\text { management framework and tools. } \\
\text { 19. Strengthen crisis management preparedness, though formalizing crisis management plan and } \\
\text { undertaking crisis simulation exercises. } \\
\text { 20. Enhance capital buffers of the Deposit Insurance Fund. } \\
\text { 21. Develop contingency plan for funding in case of failure of systemically important bank. } \\
\text { 22. Implement elements of rescue package in a way so as to minimize the moral hazard for banks. }\end{array}$ & $\begin{array}{l}S \\
S \\
L \\
S \\
S\end{array}$ \\
\hline
\end{tabular}




\begin{tabular}{|c|c|c|}
\hline \multicolumn{2}{|r|}{ Recommendations } & Timeframe /2 \\
\hline $\begin{array}{l}\text { Banking Sector } \\
\text { Regulation and } \\
\text { Supervision }\end{array}$ & $\begin{array}{l}\text { 23. Address capacity and organizational challenges. Enhance effectiveness and efficiency in banking } \\
\text { supervision by optimally redeploying existing (authorized) resources in the Banking Supervision } \\
\text { Department. } \\
\text { 24. Increase cooperation with "home" regulators of major international banks and their internal audit } \\
\text { services. } \\
\text { 25. Require that banks' external auditors provide certification that prudential reports have been prepared } \\
\text { correctly and reflect the institution's records. } \\
\text { 26. Require that senior management of a bank meet the BOT at least annually to present a full review of } \\
\text { performance and their view for the future. } \\
\text { 27. Eliminate the requirement that the opening of a new bank branch involves a physical inspection of (and } \\
\text { report on) the premises by the BOT. } \\
\text { 28. Seek hands-on assistance to ensure full implementation of all aspects of risk-based supervision. } \\
\text { 29. Identify where correspondence between the BOT and banks may be entrusted to operational or } \\
\text { supervisory level employees, without the need to obtain senior executive approval. }\end{array}$ & $\begin{array}{l}M \\
M \\
S \\
s \\
S \\
S \\
S\end{array}$ \\
\hline $\begin{array}{l}\text { Systemic } \\
\text { Liquidity } \\
\text { Management }\end{array}$ & $\begin{array}{l}\text { 30. Distinguish clearly between sterilization and intervention objectives in procedures for selling FX. } \\
\text { 31. Use REPOs only for fine-tuning operations. } \\
\text { 32. Use the SMR only for long-term structural sterilization of liquidity, with frequent changes to be avoided. } \\
\text { 33. Develop alternative monetary policy scenarios for high-probability events that affect demand for } \\
\text { liquidity. } \\
\text { 34. Expedite movement of government deposits from commercial banks to BOT. }\end{array}$ & $\begin{array}{l}\text { S } \\
S \\
S \\
M \\
\text { S }\end{array}$ \\
\hline \multicolumn{3}{|c|}{ Promoting Longer-Term Finance } \\
\hline $\begin{array}{l}\text { Capital Flows and } \\
\text { Capital Account } \\
\text { Liberalization }\end{array}$ & $\begin{array}{l}\text { 35. Revise the capital account liberalization plan to ensure that the lifting of the controls is properly } \\
\text { sequenced and coordinated with other supporting policies. } \\
\text { 36. Implement supporting measures tied to the timeframe for completing capital account liberalization. } \\
\text { 37. Keep the liberalization plan under review to account for progress in establishing the supporting } \\
\text { measures. } \\
\text { 38. Consider liberalizing the capital account vis-à-vis all countries, not just regional partners. } \\
\text { 39. Revise the FX legal framework to ensure consistency and clarity. } \\
\text { 40. Establish systematic monitoring of capital and FX transactions. }\end{array}$ & $\begin{array}{l}S \\
M \\
M \\
M \\
M \\
S\end{array}$ \\
\hline $\begin{array}{l}\text { Securities } \\
\text { Markets }\end{array}$ & $\begin{array}{l}\text { 41. Overhaul the CMS Act to strengthen independence, confer adequate inspection and investigation } \\
\text { powers on CMSA and to allow international information sharing. } \\
\text { 42. Implement the Action Plan resulting from the EAC Regional IOSCO Principles Assessment. } \\
\text { 43. Adopt legislation requiring the demutualization of the DSE and the splitting of the DSE and the CSD } \\
\text { into separate corporations, and follow through with enforcement. } \\
\text { 44. Issue regulations on licensing of market intermediaries and prudential norms for institutional investors } \\
\text { based on common standards to be agreed in the framework of the EASRA. } \\
\text { 45. Design and implement an effective risk management system for securities settlement. } \\
\text { 46. Complete the implementation of the regional linkage of the RTGS system. }\end{array}$ & $\begin{array}{l}M \\
M \\
M \\
M \\
M\end{array}$ \\
\hline Pensions & 47. Finalize the establishment of the SSRA and ensure its operations commence without delay. & $\mathrm{S}$ \\
\hline
\end{tabular}




\begin{tabular}{|c|c|c|}
\hline \multicolumn{2}{|r|}{ Recommendations } & Timeframe /2 \\
\hline & $\begin{array}{l}\text { 48. Establish MOU between SSRA and BOT to clarify the boundaries of their respective powers and } \\
\text { responsibilities. } \\
\text { 49. Identify deficiencies in SSRA Act and amend accordingly. } \\
\text { 50. Replace individual fund specific laws with single common pension law. }\end{array}$ & $\begin{array}{l}\mathrm{S} \\
\mathrm{M} \\
\mathrm{M}\end{array}$ \\
\hline Insurance & $\begin{array}{l}\text { 51. Increase minimum capital requirements for entering the industry. } \\
\text { 52. Review the disclosure requirements relating to broker-initiated business. } \\
\text { 53. Review legality of current initiatives to lessen the impact of discounting in the general insurance } \\
\text { market. } \\
\text { 54. Resolve the future of the National Insurance Corporation. } \\
\text { 55. Establish a framework to allow the introduction of formal bancassurance facilities. }\end{array}$ & $\begin{array}{l}\text { S } \\
M \\
M \\
\text { M } \\
M\end{array}$ \\
\hline Housing Finance & $\begin{array}{l}\text { 56. Design product-specific regulations for mortgages as the market expands and lenders move down } \\
\text { market. } \\
\text { 57. Implement the Housing Mortgage Liquidity Facility. } \\
\text { 58. Adopt measures to strengthen housing market infrastructure. }\end{array}$ & $\begin{array}{l}M \\
S \\
M\end{array}$ \\
\hline $\begin{array}{l}\text { Public-Private } \\
\text { Partnerships }\end{array}$ & $\begin{array}{l}\text { 59. Adopt Public Private Partnership Law and regulations; establish separate units to promote and regulate } \\
\text { these projects. } \\
\text { 60. Establish a private financial intermediary to provide long-term finance to such partnerships in } \\
\text { infrastructure. }\end{array}$ & $\begin{array}{l}M \\
M\end{array}$ \\
\hline \multicolumn{3}{|c|}{ Deepening Financial Access } \\
\hline $\begin{array}{l}\text { Financial } \\
\text { Inclusion }\end{array}$ & $\begin{array}{l}\text { 61. Develop a national financial inclusion policy and formally designate the BOT and the MOFEA to play a } \\
\text { leadership role. } \\
\text { 62. Promote financial literacy by empowering a champion to implement a national campaign. } \\
\text { 63. Promote commercial bank outreach through the use of service centers and mobile banking. } \\
\text { 64. Encourage commercial bank license applicants to have an explicit outreach strategy. } \\
\text { 65. Facilitate the transformation of microfinance institutions to microfinance companies. } \\
\text { 66. Develop a licensing framework for credit-only microfinance institutions and other credit institutions. } \\
\text { 67. Promote the formation of secondary societies/networks of savings and credit cooperatives. } \\
\text { 68. Reassess and clarify the objectives of FICO regulations. } \\
\text { 69. Establish a registrar for informal financial institutions. } \\
\text { 70. Collect, analyze and periodically publish cost of banking faced by different consumer types at each } \\
\text { bank. }\end{array}$ & $\begin{array}{l}\text { S } \\
S \\
M \\
S \\
M \\
M \\
M \\
S \\
S\end{array}$ \\
\hline $\begin{array}{l}\text { Payments } \\
\text { System }\end{array}$ & $\begin{array}{l}\text { 71. Enact National Payment Systems Act to directly address risks by providing a clear definition of } \\
\text { "irrevocability of orders" and "finality" of payments in the regulations governing the TISS, and will make } \\
\text { these regulations legally enforceable. } \\
\text { 72. Require banks to implement check clearing technology, such as Electronic Check Presentment. } \\
\text { 73. Develop a national interbank card switch. } \\
\text { 74. Establish clear guidelines for consumer protection and financial literacy in retail payments. } \\
\text { 75. Support the development of cross-border remittances by promoting competition and establishing a } \\
\text { comprehensive regulatory framework. }\end{array}$ & $\begin{array}{l}S \\
S \\
S \\
M\end{array}$ \\
\hline
\end{tabular}




\begin{tabular}{|c|c|c|}
\hline \multicolumn{2}{|r|}{ Recommendations } & Timeframe /2 \\
\hline & 76. Draft new mobile payments guidelines. & $\mathrm{M}$ \\
\hline $\begin{array}{l}\text { Development } \\
\text { Finance }\end{array}$ & $\begin{array}{l}\text { General } \\
\text { 77. Limit new public policy interventions to address specifically identified and tested financing gaps. } \\
\text { 78. Phase out the regulatory distinction between commercial banks and non-banks. } \\
\text { Credit Guarantee Schemes } \\
\text { 79. Carry out an impact assessment to assess the additionality of existing credit guarantee schemes. } \\
\text { 80. Move the management of credit guarantee schemes from the BOT to an independent commercial } \\
\text { agency. } \\
\text { 81. Consolidate the Export Credit Guarantee and Small and Medium Enterprise credit guarantee scheme } \\
\text { and tighten their terms. } \\
\text { Leasing } \\
\text { 82. Review the tax arrangements for leasing and implement reform to remove the discouraging tax } \\
\text { treatment of leasing. } \\
\text { Tanzania Investment Bank (TIB) } \\
\text { 83. Deepen the design work to reform the TIB by (i) market studies to define in detail the specific financing } \\
\text { gaps that the new TIB will seek to address; and (ii) work to design and pilot-test the particular business } \\
\text { models that will be employed. } \\
\text { 84. Decline involvement of the TIB in either infrastructure financing or in housing finance given the other } \\
\text { institutional arrangements that are being lined up to address these areas. } \\
\text { Tanzania Postal Bank (TPB) } \\
\text { 85. Identify strategic investor for TPB. } \\
\text { Agricultural Development Bank (ADB) } \\
\text { 86. Consider the ADB as a possibility only for the medium term and only after substantial planning and } \\
\text { design work has been undertaken. } \\
\text { 87. Consider the possibility to use the Agricultural Window of the TIB as a pilot test-bed to help assess the } \\
\text { types of needs and models that may be appropriate and viable for ADB. }\end{array}$ & $\begin{array}{l}\mathrm{M} \\
\mathrm{S} \\
\mathrm{M} \\
\mathrm{S} \\
\mathrm{M} \\
\mathrm{M}\end{array}$ \\
\hline
\end{tabular}

Notes:

1/ Based on Aide-Mémoire of FSAP mission, January 2010.

$2 / \mathrm{S}=$ short term (3-6 months); $M=$ medium term (1-2 years); $L=$ long term (3-5 years). 
APPENDIX II. RISK ASSESSMENT MATRIX

\begin{tabular}{|c|c|c|}
\hline Tanzania & \multicolumn{2}{|c|}{ Overall Level of Concern } \\
\hline $\begin{array}{c}\text { Nature/Source of } \\
\text { Main Threats }\end{array}$ & $\begin{array}{c}\text { Likelihood of severe realization of } \\
\text { threat sometime in the next 1-3 years }\end{array}$ & $\begin{array}{c}\text { Expected impact on financial stability if } \\
\text { threat is realized }\end{array}$ \\
\hline
\end{tabular}

A. Macroeconomic environment:

\begin{tabular}{|c|c|}
\hline & Assessment: medium \\
\hline $\begin{array}{l}\text { 1. Further weakness in } \\
\text { the world economy } \\
\text { could have adverse } \\
\text { effects on economic } \\
\text { activity in Tanzania. }\end{array}$ & $\begin{array}{l}\text { The recovery in the world economy is } \\
\text { still fragile; private demand may } \\
\text { remain weak as a result of continued } \\
\text { high unemployment, leading to } \\
\text { further weakness in the demand for } \\
\text { Tanzania's exports and exert } \\
\text { downward pressure on commodity } \\
\text { prices. }\end{array}$ \\
\hline
\end{tabular}

Risk aversion in financial markets may return, leading banks to continue to curtail credit.

\section{Assessment: medium}

Further weakness in external demand could impact export-driven sectors. If their ability to service loan obligations is affected, banks could see NPLs increase, as happened in 2008/09.

As in the current slowdown, further economic weakness would impact government finances, with possible effects on interest rates and potential crowding out of private activity.

Curtailed credit to the private sector due to banks' risk aversion would have an adverse effect on overall economic activity and borrower's ability to service existing loans.

Inadequate loan loss provisioning suggests a lesser resilience of banks to a further deterioration in loan quality. While many banks have adequate capital buffers, some lesser capitalized banks could become undercapitalized through a sharp increase in NPLs.

Weaker economic fundamentals may increase risk premiums and trigger a reduction in foreign funding for all types of loans.

\section{Assessment: medium}

A decrease in aid flows could lead to a higher fiscal deficit, growing public debt, and a wider current account deficit, driving up the country risk premium and exerting downward pressure on exchange rates.

The necessary increase in financing through domestic financial markets could increase interest rates, leading to crowding-out effects and a deterioration 


\begin{tabular}{|c|c|c|}
\hline Tanzania & \multicolumn{2}{|c|}{ Overall Level of Concern } \\
\hline $\begin{array}{l}\text { Nature/Source of } \\
\text { Main Threats }\end{array}$ & $\begin{array}{l}\text { Likelihood of severe realization of } \\
\text { threat sometime in the next } 1-3 \text { years }\end{array}$ & $\begin{array}{c}\text { Expected impact on financial stability if } \\
\text { threat is realized }\end{array}$ \\
\hline & same level of financial support. & $\begin{array}{l}\text { of the quality of banks' loan portfolios. } \\
\text { There could also be pressure for the } \\
\text { BOT to provide further direct financing to } \\
\text { the budget, which may threaten } \\
\text { macroeconomic stability and impinge on } \\
\text { the BOT's independence. } \\
\text { The budget deficit could further deteriorate } \\
\text { as debt servicing costs increase. } \\
\text { Weaker economic fundamentals may } \\
\text { increase risk premiums and trigger a } \\
\text { reduction in foreign funding for all types } \\
\text { of loans. }\end{array}$ \\
\hline $\begin{array}{l}\text { 3. Sharp and } \\
\text { protracted depreciation } \\
\text { of the FX rate may } \\
\text { cause financial and } \\
\text { economic distress. }\end{array}$ & $\begin{array}{l}\text { Assessment: medium } \\
\text { Tanzania has experienced episodes of } \\
\text { exchange rate pressure. Most } \\
\text { recently, in late } 2008 \text { foreign } \\
\text { investors appeared unwilling to roll } \\
\text { over existing deposits in financial } \\
\text { institutions. The resulting capital } \\
\text { outflow exerted a downward pressure } \\
\text { on the FX rate. The BOT increased } \\
\text { the volume of regular sales of FX and } \\
\text { smoothed fluctuations in the FX rate. } \\
\text { As a result of those interventions, the } \\
\text { U.S. dollar exchange rate stabilized } \\
\text { in early } 2009 \text { and has since } \\
\text { appreciated in real effective terms. } \\
\text { Still, future periods of exchange rate } \\
\text { instability may materialize. }\end{array}$ & $\begin{array}{l}\text { Assessment: low } \\
\text { Although financial dollarization has receded, } \\
\text { Tanzania remains relatively highly } \\
\text { dollarized country with } 30 \text { percent of } \\
\text { deposits and } 30 \text { percent of loans } \\
\text { denominated in foreign currency. A } \\
\text { sharp and protracted depreciation of the } \\
\text { FX rate could increase FX risk and credit } \\
\text { risks for banks. } \\
\text { In the past, the financial sector has coped } \\
\text { well with episodes of protracted } \\
\text { depreciation of the FX rate. In addition, } \\
\text { stress tests show the impact would be } \\
\text { manageable. } \\
\text { While some corporates have high FX } \\
\text { exposures, risk is mitigated because } \\
\text { banks limit FX loans to borrowers that } \\
\text { have a natural hedge through income in } \\
\text { foreign exchange. Still, a lack of } \\
\text { information on corporate leverage makes } \\
\text { it difficult to conduct a full risk } \\
\text { assessment. }\end{array}$ \\
\hline $\begin{array}{l}\text { 4. Recent very high } \\
\text { rates of credit growth } \\
\text { may have led to, or be } \\
\text { associated with, less } \\
\text { robust loan } \\
\text { underwriting practices } \\
\text { and may signal future } \\
\text { deteriorating loan }\end{array}$ & $\begin{array}{l}\text { Assessment: medium } \\
\text { Risk management practices have been } \\
\text { uneven across the banking sector, } \\
\text { with some banks increasing lending } \\
\text { sharply to sectors that are most } \\
\text { exposed to the economic slowdown, } \\
\text { particularly agriculture, construction, } \\
\text { and tourism. The high concentrations }\end{array}$ & $\begin{array}{l}\text { Assessment: medium } \\
\text { Stress test results from a shock to the } \\
\text { quality of the loan portfolio associated } \\
\text { with an abrupt downturn in economic } \\
\text { growth suggest that a number of banks } \\
\text { would become undercapitalized and } \\
\text { would require significant capital } \\
\text { injections. }\end{array}$ \\
\hline
\end{tabular}




\begin{tabular}{|c|c|c|}
\hline Tanzania & \multicolumn{2}{|c|}{ Overall Level of Concern } \\
\hline $\begin{array}{l}\text { Nature/Source of } \\
\text { Main Threats }\end{array}$ & $\begin{array}{l}\text { Likelihood of severe realization of } \\
\text { threat sometime in the next } 1-3 \text { years }\end{array}$ & $\begin{array}{l}\text { Expected impact on financial stability if } \\
\text { threat is realized }\end{array}$ \\
\hline portfolio quality. & $\begin{array}{l}\text { of the loan portfolios and forbearance } \\
\text { in supervision have compounded } \\
\text { credit risk. }\end{array}$ & $\begin{array}{l}\text { Trouble in one or more banks could } \\
\text { propagate through the financial system } \\
\text { as a result of shortcomings in the crisis } \\
\text { management framework, including } \\
\text { insufficient focus by supervisors on } \\
\text { systemic risk, the lack of an instrument } \\
\text { for injecting emergency liquidity, and an } \\
\text { underfunded Deposit Insurance Fund. }\end{array}$ \\
\hline $\begin{array}{l}\text { 5. Contagion from } \\
\text { economic, financial or } \\
\text { political turmoil in the } \\
\text { region. }\end{array}$ & $\begin{array}{l}\text { Assessment: low } \\
\text { Countries in the region have seen } \\
\text { periodic economic and/or political } \\
\text { upheaval. The threat of contagion to } \\
\text { Tanzania appears low, as such } \\
\text { episodes have in the past affected } \\
\text { Tanzania little, including during the } \\
\text { recent global financial turmoil. }\end{array}$ & $\begin{array}{l}\text { Assessment: medium } \\
\text { Cross border contagion of economic, } \\
\text { financial and political turmoil has been } \\
\text { limited in the past. } \\
\text { Stronger cross-border links in the financial } \\
\text { sector, through ownership or as a result } \\
\text { from the planned capital account } \\
\text { liberalization, could, however, increase } \\
\text { the impact of contagion. } \\
\text { Tanzania has } 17 \text { foreign-owned banks, of } \\
\text { which a number are from the region. } \\
\text { Distress in the home market could be } \\
\text { transmitted to Tanzania through } \\
\text { withdrawal of liquidity, repatriation of } \\
\text { capital, or failure of the parent bank. } \\
\text { Trouble in one or more banks could } \\
\text { propagate through the financial system } \\
\text { as a result of shortcomings in the crisis } \\
\text { management framework, including } \\
\text { insufficient focus by supervisors on } \\
\text { systemic risk, the lack of an instrument } \\
\text { for injecting emergency liquidity, and an } \\
\text { underfunded Deposit Insurance Fund. }\end{array}$ \\
\hline \multicolumn{3}{|c|}{ B. Weaknesses in financial regulatory/supervisory frameworks and risk management practices: } \\
\hline $\begin{array}{l}\text { 1, Weak compliance } \\
\text { with and weaknesses } \\
\text { in monitoring and } \\
\text { enforcement of } \\
\text { prudential rules may } \\
\text { trigger or compound } \\
\text { financial trouble in } \\
\text { banks. }\end{array}$ & $\begin{array}{l}\text { Assessment: medium } \\
\text { The FSAP Update mission found } \\
\text { evidences of weak compliance of } \\
\text { banks with prudential regulations, } \\
\text { e.g., as of June 2009: (i) three banks } \\
\text { were undercapitalized; (ii) a number } \\
\text { of banks had large single exposures } \\
\text { that significantly exceed the } \\
\text { prudential limits; (iii) loan to deposit } \\
\text { ratio was breached by } 11 \text { banks; and }\end{array}$ & $\begin{array}{l}\text { Assessment: high } \\
\text { Weak compliance with prudential rules } \\
\text { compromises banks' resilience to } \\
\text { economic and financial shocks. } \\
\text { Inadequate buffers in a number of banks, } \\
\text { both as measured by CARs and by loan } \\
\text { loss provisions, could trigger } \\
\text { undercapitalization in one or more banks, } \\
\text { potentially leading to bank runs and/or }\end{array}$ \\
\hline
\end{tabular}




\begin{tabular}{|c|c|c|}
\hline Tanzania & \multicolumn{2}{|c|}{ Overall Level of Concern } \\
\hline $\begin{array}{l}\text { Nature/Source of } \\
\text { Main Threats }\end{array}$ & $\begin{array}{l}\text { Likelihood of severe realization of } \\
\text { threat sometime in the next } 1-3 \text { years }\end{array}$ & $\begin{array}{l}\text { Expected impact on financial stability if } \\
\text { threat is realized }\end{array}$ \\
\hline & $\begin{array}{l}\text { (iv) there appeared to be widespread } \\
\text { non-compliance with provisioning } \\
\text { requirements. } \\
\text { In addition, the mission noted substantial } \\
\text { weaknesses in data quality, such as: } \\
\text { existing outliers in information on } \\
\text { NPLs, gaps in data collection on } \\
\text { provisioning, and lack of more } \\
\text { detailed data on loan portfolio for } \\
\text { smaller banks. These weaknesses } \\
\text { complicate efforts to monitor financial } \\
\text { stability, so that emerging risks may } \\
\text { not be detected and addressed in a } \\
\text { timely manner. }\end{array}$ & $\begin{array}{l}\text { closures. } \\
\text { Trouble in one or more banks could } \\
\text { propagate through the financial system } \\
\text { as a result of shortcomings in the crisis } \\
\text { management framework, including } \\
\text { insufficient focus by supervisors on } \\
\text { systemic risk, the lack of an instrument } \\
\text { for injecting emergency liquidity, and an } \\
\text { underfunded Deposit Insurance Fund. } \\
\text { The risk is further increased by weaknesses } \\
\text { in the quality of prudential data; the } \\
\text { condition of the financial sector could be } \\
\text { much weaker than revealed by data } \\
\text { reported by banks and emerging risks } \\
\text { may not be detected in a timely manner, } \\
\text { potentially exacerbating trouble in banks. }\end{array}$ \\
\hline $\begin{array}{l}\text { 2. Inadequate } \\
\text { supervisory framework } \\
\text { for pension funds and } \\
\text { delays in appointing a } \\
\text { single regulator may } \\
\text { trigger failures. }\end{array}$ & $\begin{array}{l}\text { Assessment: medium } \\
\text { Although unified legislation for pension } \\
\text { funds was issued in 2008, a single } \\
\text { regulatory authority (SSRA) has not } \\
\text { yet been established. The lack of } \\
\text { clear guidelines for the oversight } \\
\text { function has left pension funds } \\
\text { largely unsupervised. } \\
\text { Delays in conducting actuarial studies } \\
\text { and issuing unified investment } \\
\text { guidelines are hindering the process } \\
\text { of collecting information on pension } \\
\text { funds' performance. This makes it } \\
\text { difficult to detect any potential risks } \\
\text { stemming from pension fund asset } \\
\text { allocation and to make a fair } \\
\text { assessment of their current financial } \\
\text { condition. }\end{array}$ & $\begin{array}{l}\text { Assessment: high } \\
\text { Pension fund assets grew exponentially } \\
\text { over the last } 3 \text { years and recently } \\
\text { accounted for } 10 \text { percent of GDP (or } \\
20 \text { percent of total financial sector } \\
\text { assets). The size of pension funds' } \\
\text { assets and their role as a supplier of } \\
\text { liquidity for banks increase their } \\
\text { importance for financial sector stability, } \\
\text { with a potential spillover effect on other } \\
\text { financial institutions, if } \\
\text { illiquidity/insolvency problems emerge. } \\
\text { The role of pension funds as "liquidity } \\
\text { provider" for banks has been increasing } \\
\text { and the financial fortunes of banks and } \\
\text { pension funds are growing more } \\
\text { interconnected. Given the shallowness } \\
\text { of the domestic interbank market, highly } \\
\text { liquid pension funds have been lending } \\
\text { to banks in times of distress (cf. the } \\
\text { increase in lending since } \\
\text { November 2008). Potential trouble in } \\
\text { banks could therefore trigger financial } \\
\text { distress for pension funds. }\end{array}$ \\
\hline
\end{tabular}




\begin{tabular}{|l|l|l|}
\hline \multicolumn{1}{|c|}{ Tanzania } & \multicolumn{2}{|c|}{ Overall Level of Concern } \\
\hline \multicolumn{1}{|c|}{$\begin{array}{c}\text { Nature/Source of } \\
\text { Main Threats }\end{array}$} & $\begin{array}{c}\text { Likelihood of severe realization of } \\
\text { threat sometime in the next 1-3 years }\end{array}$ & $\begin{array}{c}\text { Expected impact on financial stability if } \\
\text { threat is realized }\end{array}$ \\
\hline $\begin{array}{l}\text { 3. Inadequately } \\
\text { managed capital } \\
\text { account liberalization. }\end{array}$ & $\begin{array}{c}\text { Assessment: medium } \\
\text { A plan for capital account liberalization } \\
\text { in the context of the EAC is being } \\
\text { prepared. As it stands, the plan } \\
\text { needs to be reviewed to ensure that } \\
\text { the lifting of the controls is properly } \\
\text { sequenced and coordinated with } \\
\text { other supporting policies. }\end{array}$ & $\begin{array}{c}\text { Assessment: } \text { medium } \\
\text { A capital account liberalization that is not } \\
\text { sufficiently accompanied by supporting } \\
\text { policies or not well sequenced may } \\
\text { trigger destabilizing capital flows. } \\
\text { Such flows may lead to sharp changes in } \\
\text { exchange rates and interest rates and } \\
\text { lead to liquidity issues in individual } \\
\text { banks, as well as systemic liquidity } \\
\text { problems. } \\
\end{array}$ \\
& & $\begin{array}{c}\text { Resulting macroeconomic distress may } \\
\text { impact borrowers and lead to repayment } \\
\text { difficulties and increases in NPLs. }\end{array}$ \\
& & \\
\hline
\end{tabular}




\section{APPENDiX III. SuMMARY OF STRESS TeSTING MeThOdOLOGY ${ }^{13}$}

\section{This appendix describes the methodology for the stress tests on the Tanzanian} banking sector carried out by the FSAP Update mission. The mission applied single factor sensitivity analysis for credit, exchange-rate, interest-rate and liquidity risks to simulate the potential impact of exceptional but plausible shocks. It also simulated the effect of adverse changes in macroeconomic conditions through a multifactor shock.

\section{The stress testing exercise suffered from major deficiencies in the data,} preventing inclusion of all banks in some stress tests. The macroeconomic scenarios and the sensitivity analysis of interest rate risk could only be done for the 10 largest banks, covering 81 percent of total assets of the Tanzanian banking sector. Stress tests for credit, exchange rate and liquidity risks were carried out for 35 banks. For analytical purposes, the banks were grouped into foreign-owned and domestically-owned institutions, or, alternatively, large, medium and small, and community banks.

\section{The stress tests included the major risks faced by banks, as follows.}

- $\quad$ The credit risk tests suffered most from data difficulties. Weak bank-level data on NPLs, lack of longer reliable and consistent time series on NPLs, and the absence of a macroeconomic model to relate loan quality to changes in macroeconomic conditions made a more sophisticated analysis of credit risk impossible. The mission chose therefore to assess general credit risk through a sensitivity analysis that assumed a large but plausible increase in NPLs. To get a sense of the magnitude of a large shock, it looked at individual bank experiences. One bank saw an increase in NPLs in the 12-month period up to end-June 2009 of 90 percent. To assume a general increase of that magnitude appeared unreasonable; to keep the change plausible, one-half of the increase was assumed, amounting to a 45 percent increase in NPLs for all banks. Because a breakdown of NPLs in categories of nonperformance was not available, the exact amount of provisioning required could not be established. To err on the side of caution, the mission assumed a relatively high average rate of provisioning of 50 percent of NPLs. Separately, stress tests of concentration risk assumed that the three largest borrowers of each bank would subsequently default.

- Exchange-rate risk was tested through applying depreciation and appreciation of the Tanzanian shilling against U.S. dollar by 30 percent. The size of the shock was

\footnotetext{
${ }^{13}$ For more details, see Technical Note "Stress Testing and Crisis Preparedness."
} 
assumed to be equal to two standard deviations of the times series calibrated using two standard deviations of the time series of the dollar rate during 2008/09. ${ }^{14}$

The test for interest rate risk also used historical data for calibration of the size of the shock. It assumed a return of long-term rates to their maximum value in the period 2005/09, i.e., an increase of 574 basis points. Two assumptions were made about short-term rates: (i) the same increase as long-term rates, i.e., 574 basis points, resulting in a parallel shift upward of the yield curve; and (ii) an increase in short rates to their maximum level in the period 2005/09, i.e., an increase of 1,839 basis points. In the latter scenario, long rates would again increase 574 basis points, with the end result that the yield curve would flatten out considerably. The stress test does not measure capital losses (as most banks hold securities to maturity). Rather, it measures the impact of repricing gaps on income, with the impact measured as a decline in net interest income over one year. With limited maturity data available, the test grouped assets and liabilities in two buckets by maturity: $<1$ year and $>1$ year, with the short rate increase applied to the former and the long rate increase to the latter. Then income and expenses over one year were calculated on assets and liabilities, respectively. The difference is the loss, which was subtracted from capital.

- $\quad$ Liquidity risk was simulated by assuming deposit withdrawals equal to two standard deviations of the quarterly time series of banks' deposit base over last five years. This assumption yielded a daily withdrawal rate of 34 percent for current deposits and 16 percent for term deposits. The test also assumed that banks would have ready access to 90 percent of liquid assets. Banks needing liquidity beyond this threshold would be considered illiquid and would fail. A second test concerned non-resident deposit withdrawals only. Due to difficulties in obtaining data on the historical volatility of non-resident deposits, and taking into consideration the fact that nonresident deposits are comparatively small and account for only 1.2 percent of total deposits, it was assumed that the shock would see a sudden withdrawal of all nonresidetn deposits, while leaving resident deposits unchanged.

- Two multi-factor shocks were simulated:

- The first multi-factor shock assumed sudden fall in global commodity prices by 30 percent. This would lead the value of exports to decline sharply, exerting pressure on the exchange rate, causing a rapid deterioration by 30 percent over one quarter. A widening current account deficit and deteriorating macroeconomic fundamentals result in a loss of confidence, and parent banks start to impose stricter limits on short-term funding for Tanzanian subsidiaries, while FDI declines. As a consequence, economic

\footnotetext{
${ }^{14}$ The size of the shock is also in line with the Fund's practice in other countries (see Stress Testing at the IMF, M. Moretti, S. Stolz, and M. Swinburne (2008)).
} 
growth falls from 5 percent to 2 percent. The assumed magnitude of the shocks was based on analysis of historical data related to commodity price shocks. ${ }^{15}$ The shock effects were estimated over two years. The paths of major macroeconomic and market variables under the baseline forecast and the stressed scenario are shown in Appendix Table 1. To estimate the effects of the combined shock on the balance sheets of banks, the effects of the single factor shocks are aggregated.

\section{Appendix Table 1. Assumptions for Multi-Factor Shock 1}

\begin{tabular}{|c|c|c|c|}
\hline Year & $\begin{array}{l}\text { Global Commodity } \\
\text { Food Price Index } \\
\text { 2006:Q2=100 }\end{array}$ & $\begin{array}{l}\text { GDP } \\
\text { Growth }\end{array}$ & TZS/USD \\
\hline \multicolumn{4}{|c|}{ Baseline forecasts } \\
\hline 2009 & 1,13 & 5,0 & 1326 \\
\hline 2010 & 1,14 & 5,6 & 1326 \\
\hline 2011 & 1,14 & 6,7 & 1326 \\
\hline \multicolumn{4}{|c|}{ Multi-factor scenario 1: deviations from the baseline } \\
\hline & $(\%)$ & $\begin{array}{c}\text { (decrease in } \\
\text { percentage points) }\end{array}$ & $(\%)$ \\
\hline 2009 & -24 & -3 & 30 \\
\hline 2010 & -25 & $-3,6$ & 30 \\
\hline 2011 & -25 & $-4,7$ & 30 \\
\hline
\end{tabular}

Source: IMF calculations.

○ Multi-factor shock 2 assumes an increase in political risk that leads to capital outflows. Withdrawal of deposits of non-residents and loans from parent banks to subsidiaries in Tanzania results in a depreciation of the Tanzanian shilling by 30 percent against the U.S. dollar. In addition, the BOT increases interest rates to prevent further depreciation of the national currency. Short

\footnotetext{
${ }^{15}$ During the 2001-03 slowdown associated with the burst of the "dot-com" bubble, global cotton prices fell by 38 percent from their peak in 2000:Q4 to a trough in 2001:Q4. During this period, coffee prices fell by almost 20 percent.

${ }^{16}$ Variables are end of period. Forecasts are based on data from futures contracts for respective periods. Data source: Bloomberg.
} 
and long-term interest rates rise: as in the single factor shock described above, the yield curve shifts upward by 574 bps. As a result, NPLs increase by 45 percent as in the case of the single factor shock. To estimate the effects of the combined shock on the balance sheets of banks, the effects of the single factor shocks are aggregated.

\section{Because of the short available time series, the multifactor stress tests used a} panel data methodology to estimate the relationship between probabilities of default (PODs) in the loan portfolios of banks and various macroeconomic variables. Quarterly data for 2006Q2-2009Q2 on loans and NPLs by sector was obtained for the ten largest banks. Given the absence of frequency PODs, proxy PODs were defined as follows: PODs ${ }_{\text {Sector }}=$ NPLs Sector $_{\text {Total Loans }}$ Sector. For econometric calculation purposes, PODs were transformed to logit format to allow for non-linearities to yield the dependent variable $\ln ($ PODs/(1-PODs). Finally, the model was specified as follows:

$$
P o D_{i, t}=c_{i}+\alpha P o D_{i, t-1}+\sum_{n=1}^{k} \beta M_{F, t} M_{F, t}
$$

where PODs $s_{i, t}$ denotes the logit transformed PODs for bank $i$ in quarter $t, C_{i}$ stands for a fixed effect for bank $\mathrm{I}, \alpha$ is the elasticity of the autoregressive term that helps to explain the impact of macro variables on changes in PODs over time, and $\beta$ denotes the elasticity of the impact of macro factor $\mathrm{M}$ at the time period $\mathrm{t}$.

\section{The analysis used a Generalized Methods of Moments (GMM) estimation} method with random effects. Hausman test results confirmed the existence of random effects in all the three equations. Inclusion of the autoregressive term made the panel dynamic; therefore a panel GMM estimation technique was applied.

\section{The initial set of macroeconomic variables included global commodity food,} coffee, cotton, gold, and fuel prices as well as domestic variables: GDP growth, a shortterm interest rate and the Tanzanian shilling/U.S. dollar exchange rate. The data were converted into logs, except for GDP growth. Panel data analysis showed a significant relationship between PODs and global commodity food prices as well as GDP. All the other variables proved to be insignificant, although their direct impact on PODs might be masked by the quality of historical data.

\section{The analysis used separate loan data for six sectors: agriculture,} manufacturing, transport, and communication, trade, personal, and other. For manufacturing, transport and communications, and other a robust econometrical relationship could not be established, so that the ad hoc assumption was made that PODs would increase by two standard deviations for each bank. For the other sectors, the estimated equations are as follows: 


\begin{tabular}{|c|c|}
\hline Sector & Equation \\
\hline \multirow{2}{*}{ Agriculture } & Y_AGR $=0.639082320896 *$ Y_AGR(-1) $-3.49839967901 *$ LPFOOD \\
\hline & $(-3.79)$ \\
\hline Manufacturing & No significant result; PODs assumed to increase by 2 standard deviations. \\
\hline $\begin{array}{l}\text { Transport and } \\
\text { communications }\end{array}$ & No significant result; PODs assumed to increase by 2 standard deviations. \\
\hline \multirow{2}{*}{ Trade } & $Y_{-}$TRD $=-2.95015617978-2.80302769957^{*}$ LPFOOD \\
\hline & $(-3.88)$ \\
\hline \multirow{2}{*}{ Personal } & Y_PER $=0.817690963642 *$ Y_PER(-1) $-18.1983769689 *$ LGDP \\
\hline & $(-1.97)$ \\
\hline
\end{tabular}

157. Losses were calculated for each bank and each sector separately. Shocked macro-variables (global commodity food prices and GDP) were inserted into the estimated equations to get shocked PODs. The difference between the current level of PODs (Q2:2009) and their forecasted level was calculated for each bank and sector for each quarter from Q3:2009 to Q2:2011. The difference was multiplied by each bank's exposure to the respective sector. A loss given default (LGD) ratio of 50 percent was applied and removed from the risk-weighted assets (RWA). Banks were assumed to make provisions equal to the current actual ratio of provisions to NPLs. Net interest income was assumed to decline in proportion to the increase in the ratio of NPLs to RWA. 


\section{Appendix IV. Basel Core Principles Assessment-Main Findings}

\section{A. Introduction}

158. This is a summary of an update assessment that was prepared in the context of the FSAP Update mission conducted during September 9 to 23, 2009. It follows a first assessment of Tanzania's compliance with the BCPs was done as part of the 2003 FSAP. The update reflects the banking supervision practices of the Bank Supervision Department (BSD) of the BOT as of end-August 2009. The assessors were Mr. Keith Bell and Mr. Richard Hands.

\section{B. Information and Methodology Used for Assessment}

159. The assessment is based on several sources: (i) interviews with staff of the BSD; (ii) a review of the legal and regulatory framework, (iii) meetings with senior officials of domestically-owned banks as well as foreign bank subsidiaries incorporated and operating in Tanzania; and (iv) an interview with a partner of a major international accounting firm active in Tanzania. A self-assessment completed by the DBS and dated September 1, 2009 had not been prepared using the structure and methodology recommended in the October 2006 BCPs Methodology document and was of marginal utility to the assessors. The present assessment was performed in accordance with the guidelines set out in the October 2006 document.

\section{Institutional and Macro-Prudential Setting_-Market Structure}

160. The financial services industry in Tanzania comprises the banking sector (i.e., universal and commercial banks), collective investment schemes, insurance business and pension funds. The industry is small but growing, and is dominated by the banking sector, which accounts for some four-fifths of the financial services industry's total assets. There are 36 licensed banks, a large majority of which are private, and foreign participation is slightly above 50 percent.

161. The banking sector comprises three main segments; large domestic banks, subsidiaries of major international banks, and the smaller-mostly domestic-banks. The three large "domestic" banks (National Bank of Commerce (NBC), National Microfinance Bank (NMB), and Cooperative and Rural Development Bank (CRDB)) account for approximately one-half of the sector's assets at end-June 2009. Four subsidiaries of major international banks (Citibank, Standard Chartered, Stanbic, and Barclays) take up a further 25 percent, with smaller banks accounting for the remainder. Asset concentrationalthough declining - is still high, with the seven noted banks accounting for almost three quarters of the total assets of the banking sector.

162. The BOT is Tanzania's bank supervisory, regulatory, and licensing authority by virtue of the Bank of Tanzania Act, 2006 and the Banking and Financial 
Institutions Act, 2006 (BFIA). It operates a fairly comprehensive and transparent system in exercising its exclusive right to grant banking licenses and to maintain observance of bank legislation and regulations.

\section{General Preconditions for Effective Banking Supervision}

163. Effective banking supervision requires a set of preconditions to be in place. These include: (i) sound and sustainable macroeconomic policies; (ii) a well-developed financial infrastructure (legal framework, accounting, and auditing); (iii) effective market discipline; (iv) procedures for efficient resolution of problems in banks; and (v) mechanisms for providing an appropriate level of systemic protection (safety net).

\section{The global financial crisis has adversely impacted the otherwise strong} macroeconomic performance and the current outlook. Economic growth was expected to slow to 4 to 5 percent in 2009 (from 7.5 percent in 2008) due to a decline in traditional exports and weakening tourism and FDI. Inflation accelerated in 2009, mainly due to increased food and fuel prices. The balance of payments came under pressure as a result of portfolio outflows and a widening current account deficit reflecting continued high import growth. Against this background, the main macroeconomic risks for the banking sector are further deterioration of growth prospects, rising unemployment, prolonged fall in commodity prices, and lower external demand for traditional exports.

165. The legal framework has changed considerably since the 2003 assessment. The Bank of Tanzania Act, 2006 (BOTA'06) and the Banking and Financial Institutions Act, 2006 (BFIA'06) detail the BOT's functions and powers regarding licensing and supervision of banks and nonbank financial institutions. Specific prudential requirements are contained in the BFIA'06 and its attendant regulations and also in directives and circulars issued by the BOT. The Companies Act 2002 that came into force in March 2006 strengthened aspects of the corporate governance framework, particularly in respect of directors' duties.

\section{Responsibility for promulgation of accounting and auditing standards rests} with the National Board of Accountants and Auditors (NBAA). The NBAA has adopted the International Financial Reporting Standards (IFRS) for application for all commercial enterprises effective July 2004. Supervised institutions must appoint annually an external auditor from a register of auditing firms approved for the purpose by the BOT and the audit must be completed in accordance with International Auditing Standards with the auditor to opine as to whether the supervised institution's financial statements have been prepared in accordance with the IFRS. The NBAA appears not well resourced to monitor and enforce compliance with accounting standards.

167. Under the BFIA'06, the BOT has extensive corrective powers. These include explicit authority to require corrective action plans from banks, including requirements for a capital plan, plans for strengthening a banks' financial position, and other measures the BOT deems necessary. Yet it is important that these powers be used effectively and in a 
timely manner, with incipient problems in banks addressed before they cause a breach of prudential limits. The assessors noted that a number of banks appeared in breach of prudential regulations as of the time of the assessment, including three banks with CARs below the required minimum.

168. Under the BFIA'06, there exists a DIF managed by the Deposit Insurance Board (DIB). The Governor of the BOT chairs the DIB and the BOT "make(s) available to the DIB such facilities and the services of such officers as are necessary for the proper and efficient exercise of the functions of the DIB". Every bank and licensed FI must contribute to the DIF in such annual amount as the DIB determines. In line with the 2003 FSAP recommendations, the DIF has been confined to a pay-box, but the DIB retains extended functions, such as liquidation responsibilities. Liquidation regulations have yet to be completed. Such regulations would allow the DIB to liquidate a failed institution outside of the provisions of the Companies Act, so as to facilitate a prompt and cost effective windingup of a failed institution.

\section{E. Principle-by-Principle Assessment}

169. The DBS has made substantial progress toward establishing its bank supervision at the level of international best practice. Overall, the assessment shows that the DBS has achieved full compliance with 4 of the 30 core principles and sub-principles (Appendix Table 3). It is largely compliant (i.e., has only minor exceptions) with 22 of the Principles and sub-principles and materially non-compliant with the remaining four. In summary, the DBS has in place the fundamentals of a sound supervisory system. The assessments are summarized below.

\section{Objectives, independence, and powers of the supervisor, CP 1}

170. The BOTA (ss. 5(3)) provides that "In the pursuit of its objectives and the performance of its tasks, the BOT shall be autonomous and accountable as provided for under this act." while the BFIA (ss. 4(1)) provides it with an exclusive authority to license, regulate and supervise all banks and "financial institutions," as defined.

171. The Director of the Directorate of Banking Supervision (DBS) reports directly to a deputy governor (Financial Stability and Deepening) of the BOT. The Directorate's Banking Supervision Department (BSD) Examiner Grade currently operates at 50 percent of authorized strength. The BOT has introduced its model of RBS which makes one examiner responsible for one bank (fellow Examiners being seconded to his/her team for onsite examination purposes). Adherence to this policy of one-bank, one-examiner appears difficult at current staffing levels.

172. Adequate resources and their efficient management appear to present a challenge for the DBS as it strives to provide timely, effective on- and offsite supervision to the current group of licensees. Not all of the BSD's examiners have laptop 
computers, although this is expected to be remedied in the short term. Examiners' available time is impacted by vetting prudential (and other statistical and economic) reports submitted on "memory sticks" to the BSD by the banks. BSD examiners appear to provide data manipulation services for other departments of the BOT. Action following detection of infractions of the BFIA (e.g., on liquidity, exposure limits, and capital adequacy) from review of data submitted involves a chain of documents to obtain hierarchical approval (which can extend to the governor if a waiver is involved).

173. Common legal protection for employees of a bank regulator performing their functions in good faith is included in the BOTA. The BOT's legal capacity for cooperation with other regulators, particularly "home" regulators of significant participants in Tanzania's banking industry, needs further exploitation.

\section{Licensing procedures, ownership and acquisitions CPs 2-5}

174. The BFIA defines permitted activities, the term "bank" and restricts its use. The BOT's prior approval is also required for establishing a bank (and its scope of operations). Moreover, its prior approval must be obtained for a bank to establish a subsidiary, branch or representative office abroad; to acquire equity holdings in a bank; or to acquire equity holdings in an entity engaged in activities otherwise not permitted for a bank or financial institution. License applications are treated in line with the detailed provisions of the BFIA and the detailed Licensing Regulations.

175. Any transfer of ownership or control involving 5 percent or more of the voting shares of a bank or other financial institution is void without grant of the BOT's prior approval. The BOT is required to assess the declared source(s) of funds of those intending to acquire shares of a bank either through a qualified holding in an existing bank or establishment of a bank and to apply a "fit and proper" test.

\section{Prudential regulations and requirements, CPs 6-18}

176. The capital adequacy requirement generally conforms to the Basel Capital Accord of 1988, but does not yet apply a capital charge for market risk. The Capital Adequacy Regulations do provide for measurement and application of capital charges in respect of market risk but, as yet, an appropriate form for the banks to apply the Standardized Measurement Method has not been prepared, although this is scheduled to be remedied in the short term. Although the IFRS is implemented by licensed banks, loan loss provisioning for capital adequacy purposes remains governed by the BOT's matrix formulation.

177. The BOT has committed significant resources to develop secondary legislation and operating methods to address requirements imposed by the BFIA and, as well, to address those areas for improvement that were highlighted in the 2003 BCPs assessment or required by the October 2006 revision of the BCPs. Specifically, 
regulations or guidelines have been issued addressing overall risk management, credit, liquidity, interest rate, FX, and operational risks, licensing, Board responsibilities, business continuity and exposure limits. Moreover, regulations, circulars, and guidelines have also been published on corporate governance, independent audit, reporting to the BOT and capital adequacy.

\section{Methods of ongoing supervision, CPs 19-24.}

178. The BSD's supervision combines offsite surveillance (using the BOT's proprietary BSIS system) and onsite examination. In 2004, the BSD began a project to introduce its model of risk-based supervision (RBS), leading to implementation on a pilot basis in 2006 and full roll-out during the BOT's July 2007-June 2008 fiscal year.

\section{Implementation did not proceed with a detailed RBS procedures manual in} hand, although in April 2007, the directorate did publish its "RBS Framework." Examination procedures outlined in that document prompted the assessors to request the working papers supporting the examination reports of a sample of four banks so that the entire process could be appreciated. Unfortunately, lack of working papers and comprehensive examination files limited the depth of the assessors' review. Although the examination reports covered the required areas, it was not possible to determine (without reference to working papers) whether the procedures had been systematically applied. According to the BSD management, work goes forward on a manual, with codified, detailed operating procedures for onsite examinations, including completion and organization of working papers.

180. All banks have been required to maintain their financial statements in accordance with the IFRS (see below) beginning with the year 2004. The BOT has not mandated a "Chart of Accounts" for banks (although it is required to do so by the BFIA) and the latter's monthly and quarterly prudential reporting involves mapping from their own internal reporting formats to those of the BOT. The BOT continues to require banks to make provisions for loss based on its matrix system and to adjust for differences with those made under application of the IFRS in the Capital Adequacy computation.

181. The BOT has a comprehensive array of measures in the event of bank distress. At the extreme, it has power to revoke a bank's operating license. The BOT can also levy monetary penalties on either banks or members of their managements for willful infringement of applicable legislation and regulations. Prompt Corrective Action Regulations were introduced in 2008, although the time lines appear potentially lengthy.

182. As regards consolidated supervision, the BFIA allows the BOT to extend supervision to bank holding companies and to banks' subsidiaries and those investee corporations in which a bank has a proprietary interest. Banks currently have a limited number of subsidiaries. 
183. Banks are required to "know their customers" and to have in place policies and procedures manuals on know-your-customer (KYC) and Anti-Money Laundering rules. None of the four examination reports reviewed by the 2009 FSAP Update assessors contained any reference to AML/KYC (CP 18).

\section{Home-host relationships, CP 25.}

184. MOUs are in force with sister regulators of the EAC countries and with the two jurisdictions (Comoros Islands and Cyprus) where Tanzanian-incorporated banks have established operations. Locally incorporated subsidiaries of foreign banks are subject to the same prudential, inspection, and reporting requirements as domestic banks.

\section{F. Recommended Action Plan}

\section{Appendix Table 2. Recommended Action Plan}

\begin{tabular}{|c|c|}
\hline Reference Principle & Recommended Action \\
\hline $\begin{array}{l}\text { Objectives, Independence, Powers, Transparency } \\
\text { and Cooperation (CP 1) }\end{array}$ & $\begin{array}{l}\text { - Staff BSD to full complement; prioritize core } \\
\text { functions. } \\
\text { - Conclude discussions to make Financial } \\
\text { Regulators Forum operational. } \\
\text { - Establish legal gateways to communication } \\
\text { with regulators (see BFIA'06: ss 48(5)). }\end{array}$ \\
\hline \multicolumn{2}{|l|}{ Permissible Activities (CP 2) } \\
\hline \multicolumn{2}{|l|}{ Licensing criteria (CP 3) } \\
\hline \multicolumn{2}{|l|}{ Transfer of Significant Ownership (CP 4) } \\
\hline \multicolumn{2}{|l|}{ Major Acquisitions (CP 5) } \\
\hline Capital adequacy (CP 6) & $\begin{array}{l}\text { Implement appropriate format for banks to } \\
\text { apply Standardized Measurement Method for } \\
\text { imposition of capital charges for market risk. }\end{array}$ \\
\hline Risk management Process (CP 7) & $\begin{array}{l}\text { - Engage experts to provide "hands on" } \\
\text { assistance in implementing RBS Framework. }\end{array}$ \\
\hline Credit risk (CP 8) & $\begin{array}{l}\text { - Engage experts to provide "hands on" } \\
\text { assistance in implementing RBS Framework. }\end{array}$ \\
\hline Problem assets, Provisions and Reserves (CP 9) & $\begin{array}{l}\text { - Engage experts to provide "hands on" } \\
\text { assistance in implementing RBS Framework. }\end{array}$ \\
\hline Large Exposure Limits (CP 10) & $\begin{array}{l}\text { - Consider imposition of a capital-related limit } \\
\text { on inter-bank deposits. } \\
\text { - Engage experts to provide "hands on" } \\
\text { assistance in implementing RBS Framework. }\end{array}$ \\
\hline Exposures to Related Parties (CP 11) & $\begin{array}{l}\text { - Engage experts to provide "hands on" } \\
\text { assistance in implementing RBS Framework. }\end{array}$ \\
\hline Country and Transfer Risks (CP 12) & $\begin{array}{l}\text { - Give further consideration to introducing } \\
\text { country exposure limits to cover placements } \\
\text { with banks, analogous to large exposure limits } \\
\text { expressed as a percentage of capital. } \\
\text { - Ensure BSIS reporting forms support } \\
\text { measurement of country by country exposure. }\end{array}$ \\
\hline
\end{tabular}




\begin{tabular}{|c|c|}
\hline Reference Principle & Recommended Action \\
\hline Market Risk (CP 13) & $\begin{array}{l}\text { - Complete introduction of market risk capital } \\
\text { requirements. } \\
\text { - Finalize changes to BSIS returns from banks. } \\
\text { - Elaborate requirements for risk limits and } \\
\text { control procedures in respect of market risk - } \\
\text { particularly FX dealing. } \\
\text { - Address examination procedure requirements } \\
\text { to satisfy EC } 3 \text { to cover - inter alia - dealer } \\
\text { open position limits, stop-loss limits, deal- } \\
\text { ticket reconciliation to confirmations and data } \\
\text { feeds available to support timely mark to } \\
\text { market information. }\end{array}$ \\
\hline Liquidity Risk (CP 14) & $\begin{array}{l}\text { - Fully implement all processes detailed in the } \\
\text { RBS Framework, including retention of } \\
\text { properly completed working papers. } \\
\text { - Ensure that examiners (and/or new recruits) } \\
\text { have necessary technical knowledge to } \\
\text { assess fully a bank's approach to liquidity } \\
\text { management as outlined in the Risk } \\
\text { Management Guidelines, including stress } \\
\text { testing. } \\
\text { - Consider fuller implementation of liquidity } \\
\text { guidelines based on maturity mismatches as } \\
\text { opposed to liquidity ratios. }\end{array}$ \\
\hline Operational Risk (CP 15) & $\begin{array}{l}\text { - Fully implement all processes detailed in the } \\
\text { RBS Framework, including retention of } \\
\text { properly completed working papers. } \\
\text { - Ensure effective liaison with external audit } \\
\text { firms, including trilateral meetings. } \\
\text { - Ensure compliance with the requirement for } \\
\text { banks proactively to advise BSD of material } \\
\text { events.. }\end{array}$ \\
\hline Interest Rate Risk in the Banking Book (CP 16) & $\begin{array}{l}\text { - Fully implement all processes detailed in the } \\
\text { RBS Framework, including retention of } \\
\text { properly completed working papers. } \\
\text { - Ensure that examiners have continuing } \\
\text { adequate training to support the judgmental } \\
\text { aspects of assessing a bank's interpretation of } \\
\text { the Risk Management Guidelines, including } \\
\text { models and stress tests. }\end{array}$ \\
\hline Internal Control and Audit (CP 17) & $\begin{array}{l}\text { - Fully implement all processes detailed in the } \\
\text { RBS Framework, including retention of } \\
\text { properly completed working papers. } \\
\text { - Include assessment of Compliance function in } \\
\text { examination processes. }\end{array}$ \\
\hline Abuse of Financial Services (CP 18) & $\begin{array}{l}\text { - Confirm that standards on which banks are } \\
\text { examined are fully consistent with legal } \\
\text { requirements. } \\
\text { - Integrate the processes outlined in the } \\
\text { proposed work papers on AML/CFT } \\
\text { Compliance function }\end{array}$ \\
\hline
\end{tabular}




\begin{tabular}{|c|c|}
\hline Reference Principle & Recommended Action \\
\hline Supervisory Approach (CP 19) & $\begin{array}{l}\text { - Fully implement all processes detailed in the } \\
\text { RBS Framework, including retention of } \\
\text { properly completed working papers. Consider } \\
\text { engaging on contract experienced RBS } \\
\text { practitioners to provide "hands-on" guidance } \\
\text { and skill transference. }\end{array}$ \\
\hline Supervisory Techniques (CP 20) & $\begin{array}{l}\text { As for CP 19, above, plus consider: } \\
\text { - requiring senior management to meet BSD } \\
\text { officers at least once annually beyond the } \\
\text { annual examination; } \\
\text { - having management submit commentary with } \\
\text { quarterly reports (as they must-or should- be } \\
\text { doing for their own reporting chain); } \\
\text { - holding tri-lateral meetings as contemplated } \\
\text { by the BFIA.'06 }\end{array}$ \\
\hline Supervisory Reporting (CP 21) & $\begin{array}{l}\text { - Establish whether BSD is going to conform to } \\
\text { the BFIA ss 22(1). The latter's text is clear; if } \\
\text { DBS considers the provision of marginal utility } \\
\text { it should be removed. Render more efficient } \\
\text { the process of capture and input of data to } \\
\text { BSIS - the current procedure is exhaustive of } \\
\text { BSD Examination Grade personnel's time. }\end{array}$ \\
\hline Accounting and Disclosure (CP 22) & $\begin{array}{l}\text { Establish whether BSD is going to conform to } \\
\text { the BFIA ss 22(1). The latter's text is clear; if } \\
\text { DBS considers the provision of marginal utility } \\
\text { it should be removed. Render more efficient } \\
\text { the process of capture and input of data to } \\
\text { BSIS - the current procedure is exhaustive of } \\
\text { BSD Examination Grade personnel's time. }\end{array}$ \\
\hline $\begin{array}{l}\text { Supervisors' Corrective and Remedial Powers } \\
\text { (CP 23) }\end{array}$ & $\begin{array}{l}\text { - Address infractions "forthwith" and achieve } \\
\text { resolution in a "timely manner". Consider } \\
\text { tightening the time lines of the PCAR (which } \\
\text { have provisions that could impede "prompt" } \\
\text { resolution.). }\end{array}$ \\
\hline \multicolumn{2}{|l|}{ Consolidated Supervision (CP 24) } \\
\hline Home-Host relationships (CP 25) & $\begin{array}{l}\text { - Ensure that an MOU (or at least frequent } \\
\text { contact) is in place with "home' regulators" of } \\
\text { banks incorporated in Tanzania. } \\
\text { - Increase reliance on foreign banking group } \\
\text { internal audit units where competence level } \\
\text { warrants. }\end{array}$ \\
\hline
\end{tabular}

\section{G. Authorities' Response to the Assessment}

185. The authorities welcomed the assessment's acknowledgement of the actions taken to eliminate deficiencies raised in the $\mathbf{2 0 0 3}$ assessment, particularly as regards the legislative framework underpinning the BOT's supervisory processes. Equally, the 
authorities noted the recognition accorded their substantive efforts toward imposition of effective risk management practices and procedures at all licensed banks.

186. The authorities broadly agreed with assessment's comments and concerns regarding resources and their optimum deployment. The authorities recognize that capacity and organizational challenges exist and indicated that they will take action to address these with urgency, agreeing that engagement of suitably qualified staff for vacant positions is essential. Moreover, "hands-on" expertise will be sought as one means to achieve full implementation of the BOT's program of RBS.

187. The authorities also welcomed most of the other recommendations made by the assessors. They noted, however, that the requirement that branches be inspected prior to opening has been a powerful tool to improve security and prefer to continue the practice. They indicated, however, that organizational changes will be implemented to relieve supervision staff from this duty.

188. The authorities noted that the ratings that the assessors assigned to a number of core principles appeared in large part to have been influenced by the absence of working papers and felt that the assessors' judgment on this point was excessively negative. They indicated that working papers are required and usually prepared by examiners; it is only their storage that is disorganized. 


\section{Appendix Table 3. Summary Compliance of the Basel Core Principles}

\begin{tabular}{|l|c|c|c|c|c|}
\hline \multicolumn{1}{|c|}{ Core Principle } & $\mathrm{C}^{1 /}$ & $\mathrm{LC}^{\underline{2}}$ & $\mathrm{MNC}^{3 /}$ & $\mathrm{NC}^{4 /}$ & $\mathrm{NA}^{5 /}$ \\
\hline $\begin{array}{l}\text { 1. Objectives, Autonomy, Powers, and } \\
\text { Resources }\end{array}$ & & $\mathbf{X}$ & & & \\
\hline 1.1 Responsibilities and Objectives & & $\mathbf{X}$ & & & \\
\hline $\begin{array}{l}\text { 1.2 Independence, Accountability and } \\
\text { Transparency }\end{array}$ & & $\mathbf{X}$ & & & \\
\hline 1.3 Legal framework & $\mathbf{X}$ & & & & \\
\hline 1.4 Legal powers & & & & & \\
\hline 1.5 Legal protection & & $\mathbf{X}$ & & & \\
\hline 1.6 Cooperation & $\mathbf{X}$ & & & & \\
\hline 2. Permissible Activities & $\mathbf{X}$ & & & & \\
\hline 3. Licensing Criteria & $\mathbf{X}$ & & & & \\
\hline 4. Transfer of Significant Ownership & $\mathbf{X}$ & & & & \\
\hline 5. Major Acquisitions & & $\mathbf{X}$ & & & \\
\hline 6. Capital Adequacy & & $\mathbf{X}$ & & & \\
\hline 7. Risk Management Process & & $\mathbf{X}$ & & & \\
\hline 8. Credit Risk & & $\mathbf{X}$ & & & \\
\hline 9. Problem Assets, Provisions and Reserves & & $\mathbf{X}$ & & & \\
\hline 10.Large Exposure Limits & & $\mathbf{X}$ & & & \\
\hline 11. Exposures to Related Parties & & & $\mathbf{X}$ & & \\
\hline 12. Country and Transfer Risks & & & $\mathbf{X}$ & & \\
\hline 13. Market Risks & & $\mathbf{X}$ & & & \\
\hline 14. Liquidity Risk & & $\mathbf{X}$ & & & \\
\hline 15. Operational Risk & & $\mathbf{X}$ & & & \\
\hline 16. Interest Rate Risk in the Banking Book & & $\mathbf{X}$ & & & \\
\hline 17. Internal Control and Audit & & $\mathbf{X}$ & & & \\
\hline 18. Abuse of Financial Services & & $\mathbf{X}$ & & & \\
\hline 19. Supervisory Approach & & & & \\
\hline 20. Supervisory Techniques & & & & \\
\hline 21. Supervisory Reporting & & & & \\
\hline 22. Accounting and Disclosure & & & & \\
\hline $\begin{array}{l}\text { 23. Corrective and Remedial Powers of } \\
\text { Supervisors }\end{array}$ & & & & \\
\hline 24. Consolidated Supervision & & & & \\
\hline 25. Home-Host Relationships & & & & \\
\hline
\end{tabular}

Notes:

1/ C: Compliant.

2/ LC: Largely compliant.

3/ MNC: Materially non-compliant.

${ }^{4 /}$ NC: Non-compliant.

5/ NA: Not applicable. 